\title{
Concentration and Biomagnification of Heavy Metals in Biota of the Coastal Marine Areas of Tanzania
}

\author{
Sharifa Omar Bungala, John Ferdinand Machiwa and Daniel Abel Shilla \\ Department of Aquatic Sciences and Fisheries, University of Dar es Salaam, Dar es Salaam 35064, Tanzania
}

\begin{abstract}
The concentrations of heavy metals ( $\mathrm{As}, \mathrm{Hg}, \mathrm{Cr}, \mathrm{Pb}$ and $\mathrm{Zn}$ ) were measured in the macroalgae, macrobenthos and fish from the Tanzanian coastal marine environment in order to ascertain the biomagnification using stable isotopes of $\mathrm{C}$ and $\mathrm{N}$. Macroalgae samples from the central marine areas of the Tanzanian coast had higher mean concentrations of $\mathrm{Hg}(0.17 \pm 0.01 \mu \mathrm{g} / \mathrm{g})$ and $\mathrm{Cr}(23.7 \pm 4.15 \mu \mathrm{g} / \mathrm{g})$ compared to other locations. Higher concentration of $\mathrm{Hg}(0.06 \pm 0.02 \mu \mathrm{g} / \mathrm{g})$ was detected in the Ulva fasciata close to the Msimbazi Creek in Dar es Salaam, whereas the highest concentration of $\mathrm{Cr}(45.5 \pm 6.83 \mu \mathrm{g} / \mathrm{g})$ was found in Ulva petrusa near Dar es Salaam port. The crab Portunus pelagicus collected from Pangani river estuary contained $411.5 \pm 13.04 \mu \mathrm{g} / \mathrm{g}$ of $\mathrm{Zn}$. The other metals were uniformly distributed in macrobenthos from the entire coast. Mercury and lead in the biota were found to biomagnify along the Arius dussumieri and Lethrinus lentjan food chains as suggested by the significant positive relationships between log-pollutant concentrations in fish muscle tissues vs. $\delta^{15} \mathrm{~N}$ signatures. Zinc in muscle tissues was found to be transferred along the food webs although no biomagnification was observed. Arsenic and chromium were found to decrease with the rise of the trophic position. Metal concentrations in macroalgae, macrobenthos and fish were compared with quality guidelines values by FAO (Food and Agricultural Organization) in 1983 and they all were below permissible limits for human consumption.
\end{abstract}

Key words: Heavy metals, food chains, bioconcentration, biomagnification, stable isotope ratios, $\delta^{13} \mathrm{C}, \delta^{15} \mathrm{~N}$, TL (Trophic Level).

\section{Introduction}

The term bioaccumulation refers to the net accumulation of a chemical by an aquatic organism as a result of uptake from all environmental sources (water, food and sediment). Bioaccumulation can be viewed as a result of competing rates of chemical uptake and elimination (chemical loss) by aquatic organisms. When the rates of chemical uptake and elimination achieve balance, the distribution of the chemical between the organism and its source(s) is said to be at steady-state [1]. Under steady-state conditions, a BAF (Bioaccumulation Factor) is defined as the ratio of the concentration of a chemical in the tissue of an aquatic organism to its concentration in water, in situations where both the organism and its food are exposed [1]. Aquatic organisms accumulate and retain certain chemicals

Corresponding author: Sharifa Omar Bungala, Ph.D. student, main research fields: investigation of heavy metals, organochlorines and radionuclides in aquatic food chains. when exposed to these chemicals through water, their diet and sediments [2].

Biomagnification therefore is a process where chemical substances are transferred from food to an organism resulting in higher concentrations compared with the source [3-5]. Biomagnification can also be defined as the increase in concentration of chemicals between TLs (Trophic Levels). If the biomagnification factor (concentration in predator/concentration in prey) is greater than one, then the element is biomagnified in the body of a predator.

At the first TL, only direct accumulation of heavy metals from the water occurs. In considering phytoplankton, the degree of pollutant association with the cell is generally directly related to the extracellular concentration. Dead cells concentrate metals comparable to living ones indicating that the initial association of a metal with the cells is governed by adsorption [6]. Bioconcentration is the uptake of contaminant from water by aquatic organisms where water is the only pathway and is measured as a BCF 
(Bioconcentration Factor). The BCF is most useful for low TL organisms such as phytoplankton and macroalgae, which are in rapid equilibrium with chemicals with low $\log \mathrm{K}_{\text {ow }}$ (up to 5) in water [7]. BCFs do not account for biomagnification of chemicals in the food webs [8]. Hence for larger, higher TL organisms, BCF has been shown to underestimate bioaccumulation potential for hydrophobic compounds that have $\log \mathrm{K}_{\mathrm{ow}}$ values greater than or equal to 4.5 [8].

The role of food chains in carrying contaminants to top predator fish which is a possible source for human dietary exposure, has received attention for several decades [9-15]. The trophic transfer (trophodynamics) of elements along a food chain can result in an increase (biomagnification), a decrease (biodilution) or even may cause no change in elemental concentration along that particular food chain [16]. The trophodynamics of mercury $(\mathrm{Hg})$ has been well studied and shows consistent biomagnification trends [12-15]. Other elements such as iron have been reported as not biomagnifying in food webs [9]. For other elements such as rubidium, selenium, cadmium, copper, zinc and silver, there is a growing number of studies demonstrating their biomagnification depending on site and metal-species specific factors [17-19]. Due to the deleterious effects of metals to aquatic ecosystems, it is necessary to monitor their levels in key species, because this will give an indication of the temporal and spatial extent of the accumulation and biomagnification as well as an assessment of the potential impact to human health [17].

Stable isotopes analysis has been used to study the ecological significance of materials from different sources in permanent lakes [5, 20], streams and rivers $[10,11]$, estuaries and bays [21, 22] and seas [23, 24]. This technique has also been used to describe trophic relationships between animals in a variety of terrestrial [25], fresh water [26] and marine [27, 28] environments. However, the great majority of these studies have been conducted in temperate systems, and information on the sources of energy and food web structure in tropical aquatic systems in general and in estuaries of Tanzania in particular is still lacking. TP (Trophic Position) can be related with contaminant concentrations in order to trace the pathways of contaminant biomagnification by top predators in aquatic and terrestrial food webs [14, 29, 30]. Net bioaccumulation of an element occurs when its trophic transfer is greater than that of carbon and the concentration thus increases with increasing TL $[31,32]$.

In this study, accumulation of heavy metal $\mathrm{As}, \mathrm{Hg}$, $\mathrm{Cr}, \mathrm{Pb}$ and $\mathrm{Zn}$ in macroalgae, macrobenthos and fish were analysed to determine biomagnification in the food chains of the marine catfish $A$. dussumieri and the snapper L. lentjan. The study sought to ascertain the safety of sea food from the coastal marine areas of Tanzania.

\section{Materials and Methods}

\subsection{Study Area}

This study was executed in the coastal waters of Tanzania in the western Indian Ocean. The coastal area of Tanzania (Fig. 1) encompasses a number of habitats that include coral reefs, mangroves, seagrass beds, sand banks, wetlands and beaches which support various resources both living and nonliving, and provides life support to coastal communities where such activities as fisheries and related activities play an important role in the social and economic development of local communities. The coastal areas (Dar es Salaam, Tanga, Zanzibar and Mtwara) are faced with expanding populations and emerging land-based activities such as agriculture, mineral exploitation and industrial activities which exert pressures on coastal waters, thus negatively affecting water quality. It receives water from both rivers as well as large amounts of domestic and industrial effluents. The studied area are also characterised by local harbour activities while at Dar es Salaam port 


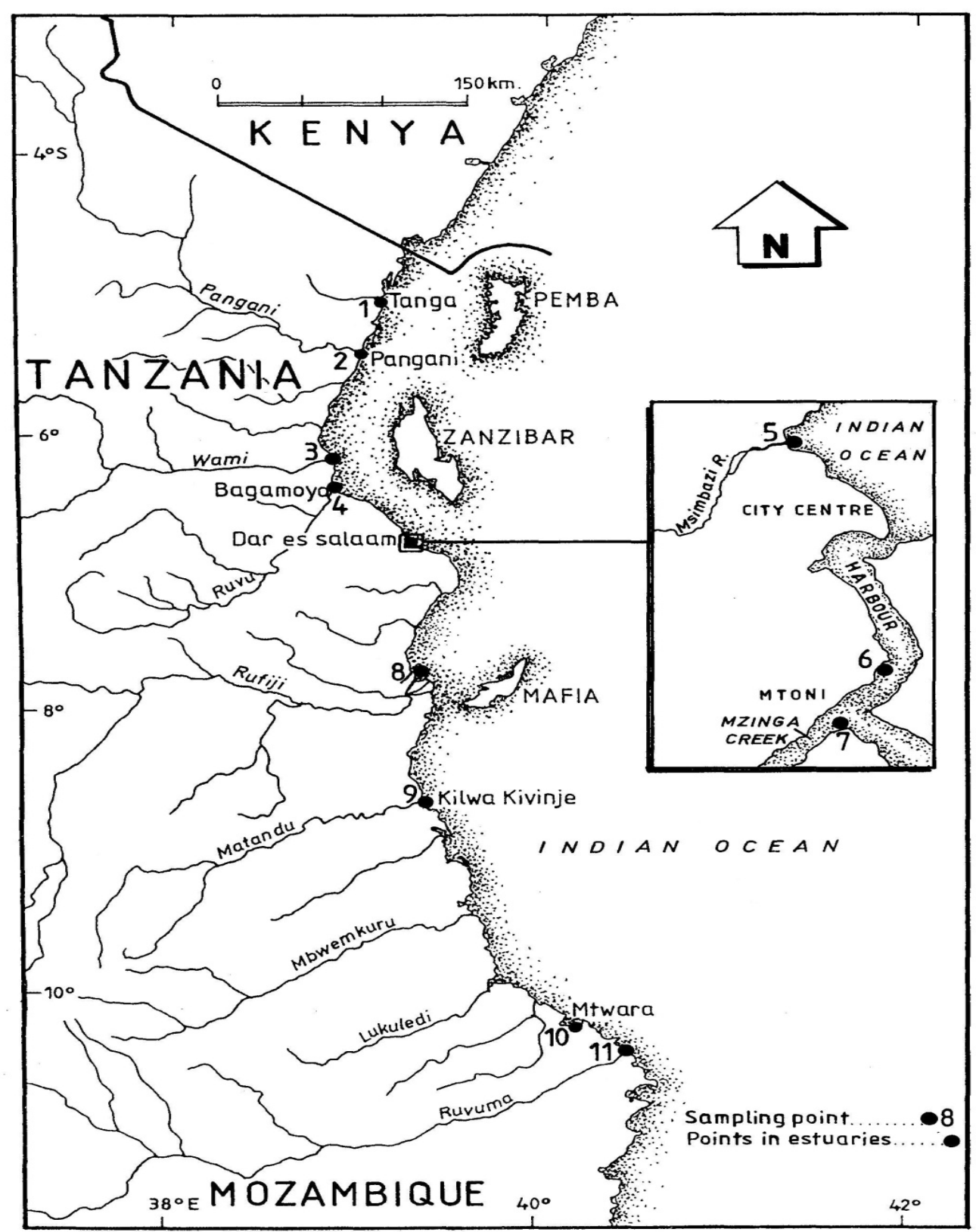

Fig. 1 Map of the marine coast of Tanzania showing the eleven sampling stations.

area, Mtwara port area and Tanga port area, there are harbour and ship fumigation activities and also loading and offloading of different types of cargo.

\subsection{Establishment of the Sampling Stations}

Eight sampling stations were located in the estuarine of rivers and three in marine areas near ports. Water, sediments and biota were collected from estuaries of these rivers: Pangani, Wami, Ruvu, Mzinga, Msimbazi, Rufiji, Matandu and Ruvuma (Fig.
1). The port areas from which samples were collected were Dar es Salaam, Tanga and Mtwara (Fig. 1). The positions of sampling stations were determined using a Geographical Positioning System (Garmin GPS 72), as shown in Table 1. Three sites were established which are NCMAs (Northern Coastal Marine Areas) (stations 1, 2, 3 and 4), CCMAs (Central Coastal Marine Areas) (stations 5, 6 and 7) and SCMAs (Southern Coastal Marine Areas) (stations 8, 9, 10 and 11). 
Table 1 Sampling locations in estuaries and port areas along the coastal marine areas of Tanzania.

\begin{tabular}{|c|c|c|c|}
\hline Site & Location & Station & Coordinates \\
\hline \multirow{4}{*}{ NCMAs } & TPA (Tanga Port Area) & 1 & $5^{\circ} 1.43^{\prime} \mathrm{S}, 39^{\circ} 5.16^{\prime} \mathrm{E}$ \\
\hline & PRE (Pangani River Estuary) & 2 & $5^{\circ} 25.46^{\prime} \mathrm{S}, 38^{\circ} 58.01^{\prime} \mathrm{E}$ \\
\hline & WRE (Wami River Estuary) & 3 & $6^{\circ} 7.17^{\prime} \mathrm{S}, 38^{\circ} 48.53^{\prime} \mathrm{E}$ \\
\hline & RRE (Ruvu River Estuary) & 4 & $6^{\circ} 24.03^{\prime} \mathrm{S}, 38^{\circ} 52.02^{\prime} \mathrm{E}$ \\
\hline \multirow{3}{*}{ CCMAs } & MRE (Msimbazi River Estuary) & 5 & $6^{\circ} 47.50^{\prime} \mathrm{S}, 39^{\circ} 16.54^{\prime} \mathrm{E}$ \\
\hline & DPA (Dar es Salaam Port Area) & 6 & $6^{\circ} 51.32^{\prime} \mathrm{S}, 39^{\circ} 17.49^{\prime} \mathrm{E}$ \\
\hline & MZC (Mzinga Creek) & 7 & $6^{\circ} 52.19^{\prime} \mathrm{S}, 39^{\circ} 17.21^{\prime} \mathrm{E}$ \\
\hline \multirow{4}{*}{ SCMAs } & RRE (Rufiji River Estuary) & 8 & $7^{\circ} 44.32^{\prime} \mathrm{S}, 39^{\circ} 19.11^{\prime} \mathrm{E}$ \\
\hline & MAE (Matandu River Estuary) & 9 & $8^{\circ} 43.26^{\prime} \mathrm{S}, 39^{\circ} 21.41^{\prime} \mathrm{E}$ \\
\hline & MPA (Mtwara Port Area), & 10 & $10^{\circ} 16.18^{\prime} \mathrm{S}, 40^{\circ} 11.13^{\prime} \mathrm{E}$ \\
\hline & RVE (Ruvuma River Estuary) & 11 & $10^{\circ} 29.35^{\prime} \mathrm{S}, 40^{\circ} 24.58^{\prime} \mathrm{E}$ \\
\hline
\end{tabular}

\subsection{Collection of Biota Samples}

Biota samples were collected from eleven sampling stations along the coastal marine area of Tanzania (Fig. 1). At each station, different species of marcoalgae and seagrass were collected (hand-picked) for heavy metals analysis.

Prawns and shrimps were captured during low tide with a $12-\mathrm{mm}$ mesh seine net, while gastropods and crabs were also hand-picked. These macrobenthos collected from the subtidal or intertidal areas were transported to the laboratory where they were identified using procedure of Richmond, M. D. [33]. The molluscs (gastropods and bivalves) and crustaceans (crabs and shrimps) from A. dussumieri and L. lentjan food chains were dissected from their exoskeleton or shells (using dissecting kits) prior to freeze-drying. Macrobenthos tissues were freeze dried for 3 days at $-60{ }^{\circ} \mathrm{C}$ and grounded into powder using a mortar and pestle.

Samples of the catfish, the emperor and some other fish were purchased from fishers in the sampling sites. Most of the fish were caught by using hook and line and some by gill netting in the estuaries and port areas. Small fish were collected along with macrobenthos using a 12-mm mesh seine net. The collected fish were counted, weighed and identified using procedure of Bianchi, G. [34] and Richmond, M. D. [33]. Total length of each fish was measured to the nearest centimeter and their wet weight established. Muscle tissue was taken from each fish for heavy metals analysis.

For stable isotopes analysis, the tissues were freeze-dried to constant weight for three days at -60 ${ }^{\circ} \mathrm{C}$ and homogenized by grinding into powder using agate mortar and pestle. Using the catfish $A$. dussumieri and the emperor L. lentjan as examples of higher trophic consumer, all organisms that were found to be part of their food web (as deduced from the gut content analysis results) were selected for isotopic analyses from all sampling sites. The same organisms were analysed for heavy metal accumulation.

\subsection{Sample Digestion and Analysis of Heavy Metals (Laboratory Analyses)}

The homogenized powder of the freeze dried biota was accurately weighed $(0.5 \mathrm{~g})$ and digested with 5 $\mathrm{mL}$ of concentrated $\mathrm{HNO}_{3}$ for 1 hour at room temperature in a Teflon beaker (covered with watch glass). The samples were then heated at $80{ }^{\circ} \mathrm{C}$ on hot plate for 4 hours. The solution was then allowed to evaporate to $2.5 \mathrm{~mL}$ and cooled and diluted to $50 \mathrm{~mL}$ with Mill-Q water [35]. The analysis of $\mathrm{As}, \mathrm{Hg}, \mathrm{Cd}$, $\mathrm{Cr}$ and $\mathrm{Zn}$ in the samples was performed on an ICP-OES (Inductively Coupled Plasma-Optical Emission Spectroscopy), Horiber Jobin Yvon, UltimA 2 at the SEAMIC (Southern and Eastern African Mineral Centre), Dar es Salaam. The instrument was calibrated using relevant standards (Merck, Germany). 
Analytical blanks were run in the similar way as that of the samples and the concentrations were determined using the standard solutions prepared in the same acid matrix. The concentration of metals in biota is expressed in dry weight basis ( $\mu \mathrm{g} / \mathrm{g}$ d.w.).

\subsection{Quality Control}

The accuracy of the method was checked by analysing certified reference material DORM-2 (dogfish muscle) from the National Research Council of Canada. The accuracy of the determination of heavy metals in the DORM-2 was good; it ranged from $95 \%$ to $99 \%$ (Table 2).

\subsection{Statistical Analysis}

Statistical analyses were performed using SPSS 16.0 for Windows, Microsoft excel and PRIMER 6. Results of the heavy metal analyses in biota were subjected to a one-way ANOVA (Analysis of Variance) to test for significant differences $(p=0.05)$ in the concentrations of the heavy metals in the tissues of the different species of biota at different sampling sites. The overall consumer isotope signatures $\left(\delta^{13} \mathrm{C}\right.$ and $\delta^{15} \mathrm{~N}$ ) among sites were tested by Pearson rank correlation and linear regression analysis with the concentration of heavy metals. Heavy metals concentrations were $\log _{10}$-transformed to reduce the differences and kurtosis of the raw data prior to statistical analysis.

\section{Results}

\subsection{Heavy Metal Concentrations in Biota Samples}

\subsubsection{Arsenic}

The mean concentration of As in macroalgae was highest $(4.10 \pm 1.51 \mu \mathrm{g} / \mathrm{g})$ in samples from NCMAs (stations 1, 2, 3 and 4) of Tanzania in comparison with
$(2.27 \pm 0.61 \mu \mathrm{g} / \mathrm{g})$ in samples from CCMAs (stations 5, 6 and 7) of Tanzania. The lowest concentration $(0.30 \pm 0.01 \mu \mathrm{g} / \mathrm{g})$ was in samples from the SCMAs (stations 8, 9. 10 and 11) of Tanzania (Fig. 2). There was significant difference (ANOVA $\mathrm{p}<0.05, \mathrm{~F}=$ 1.023) between As concentration in macroalgae from the three coastal locations (Table 3 ). The maximum concentration of As $(8.30 \pm 1.91 \mu \mathrm{g} / \mathrm{g})$ was measured in S. asperifolium from Ruvu river estuary (station 4), while the lowest concentration $(0.10 \pm 0.01 \mu \mathrm{g} / \mathrm{g})$ was reported in the Chaetomorpha sp. also from Ruvuma river estuary (station 11).

The results show that, bivalves from the CCMAs had relatively higher concentrations of As ( $3.17 \pm 1.22$ $\mu \mathrm{g} / \mathrm{g}$ ) as compared to $2.88 \pm 1.02 \mu \mathrm{g} / \mathrm{g}$ and $1.87 \pm 0.14$ $\mu \mathrm{g} / \mathrm{g}$ measured from SCMAs and NCMAs respectively (Fig. 3). There was significant difference (ANOVA $\mathrm{p}$ $<0.05, \mathrm{~F}=5.935)$ in As contents in molluscan bivalves collected from the three coastal marine areas (Table 3). Higher concentration of As (4.00 \pm 0.02 $\mu \mathrm{g} / \mathrm{g}$ ) was found in A. arcuatula from Dar es Salaam port area and Crassostrea sp. from Ruvuma river estuary, while the lowest concentration $(1.00 \pm 0.12$ $\mu \mathrm{g} / \mathrm{g}$ ) was measured in Crassostrea $s p$. from Tanga port area (Fig. 3). Significantly (ANOVA, p $>0.05, \mathrm{~F}$ $=0.457)$ higher concentrations of As $(2.25 \pm 0.18$ $\mu \mathrm{g} / \mathrm{g}$ ) were measured in crustaceans from the NCMAs while levels found in samples from CCMAs and SCMAs were $2.08 \pm 0.36 \mu \mathrm{g} / \mathrm{g}$ and $1.94 \pm 0.19 \mu \mathrm{g} / \mathrm{g}$ respectively (Fig. 4). The highest concentration of As $(4.00 \pm 1.11 \mu \mathrm{g} / \mathrm{g})$ was measured in the shrimp $P$. indicus from Msimbazi river estuary, while the lowest concentration $(0.50 \pm 0.02 \mu \mathrm{g} / \mathrm{g})$ was found in the crab P. pelagicus from Matandu river estuary (Fig. 4).

Levels of As recorded in fish species from the CCMAs was relatively higher $(3.40 \pm 1.03 \mu \mathrm{g} / \mathrm{g})$

Table 2 Mean $( \pm$ SD) concentration of metals $(\mu \mathrm{g} / \mathrm{g})$ in the certified reference material DORM-2 (SD: Standard Deviation).

\begin{tabular}{llllll}
\hline & $\mathrm{As}$ & $\mathrm{Hg}$ & $\mathrm{Cr}$ & $\mathrm{Pb}$ & $\mathrm{Zn}$ \\
\hline Certified & $18 \pm 1.7$ & $4.64 \pm 0.26$ & $34.7 \pm 5.5$ & $0.065 \pm 0.007$ & $25.6 \pm 2.3$ \\
Observed & $17.5 \pm 3.2$ & $4.43 \pm 0.27$ & $34.4 \pm 3.2$ & $0.062 \pm 0.009$ & $25.3 \pm 1.9$ \\
\% recovery & 97.2 & 95.4 & 99.1 & 95.5 & 98.8 \\
\hline
\end{tabular}




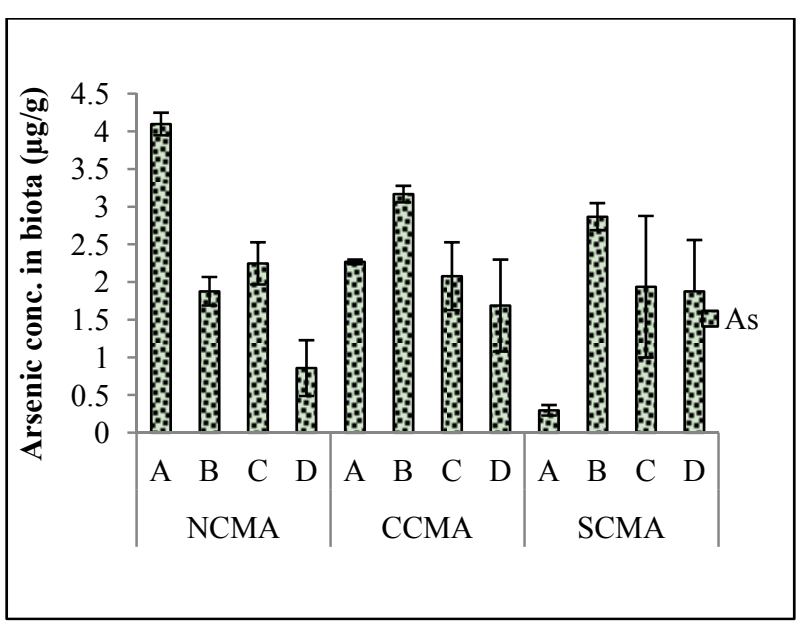

Fig. 2 Concentration (mean $\pm \mathrm{SD}$ ) of As in biota samples ( $A$ = macroalgae; $B$ = bivalves; $C=$ crustaceans; $D=$ fish) from the NCMAs, the CCMAs and the SCMAs.

compared to $2.08 \pm 0.97 \mu \mathrm{g} / \mathrm{g}$ and $0.62 \pm 0.14 \mu \mathrm{g} / \mathrm{g}$ in fish species from SCMAs and NCMAs respectively (Fig. 5). As content $(7.80 \pm 2.03 \mu \mathrm{g} / \mathrm{g})$ found in the zoobenthivorous fish $P$. quadrilineatus from Mtwara port area (station 10) was significantly higher than concentrations measured in the omnivorous fish $A$. dussumieri $(0.10 \pm 0.04 \mu \mathrm{g} / \mathrm{g})$ from Matandu river estuary (ANOVA $\mathrm{p}<0.05, \mathrm{~F}=0.583$ ) (Table 3 ). As concentrations in fish were compared with quality guidelines values FAO (Food and Agricultural Organization) [36] and they all were below permissible limits of $1.4 \mu \mathrm{g} / \mathrm{g}$ w.w. (Table 4 ).

\subsubsection{Mercury}

The mean concentration of mercury in macroalgae samples was almost similar $(0.03 \pm 0.01 \mu \mathrm{g} / \mathrm{g})$ in samples from SCMAs, NCMAs and CCMAs. There was significant difference (ANOVA $\mathrm{p}<0.05, \mathrm{~F}=$ 1.286) in $\mathrm{Hg}$ concentration in macroalgae from the three coastal marine areas of Tanzania (Table 3 ). The maximum concentration of $\mathrm{Hg}(0.06 \pm 0.03 \mu \mathrm{g} / \mathrm{g})$ was found in the $U$. fasciata from Msimbazi river estuary, while the lowest concentration of the metal $(0.01 \pm$

Table 3 ANOVA, heavy metal concentrations in macroalgae, macrobenthos, crustaceans and fish samples.

\begin{tabular}{|c|c|c|c|c|c|}
\hline & Sum of squares & Df* & Mean square & $\mathrm{F}$ & Sig. \\
\hline \multicolumn{6}{|c|}{ Macroalgae } \\
\hline As & 38.031 & 7 & 5.433 & 1.023 & 0.544 \\
\hline $\mathrm{Hg}$ & 0.002 & 7 & 0 & 1.286 & 0.457 \\
\hline $\mathrm{Cr}$ & $1,774.511$ & 7 & 253.502 & 5.778 & 0.089 \\
\hline $\mathrm{Pb}$ & 10.259 & 7 & 1.466 & 0.402 & 0.855 \\
\hline $\mathrm{Zn}$ & $13,789.41$ & 7 & $1,969.916$ & 0.28 & 0.925 \\
\hline \multicolumn{6}{|c|}{ Bivalves } \\
\hline As & 10.386 & 7 & 1.484 & 5.935 & 0.086 \\
\hline $\mathrm{Hg}$ & 0.001 & 7 & 0 & 1.223 & 0.476 \\
\hline $\mathrm{Cr}$ & 354.784 & 7 & 50.683 & 2.153 & 0.284 \\
\hline $\mathrm{Pb}$ & $1,787.67$ & 7 & 255.381 & 3.201 & 0.184 \\
\hline $\mathrm{Zn}$ & $1,054,670$ & 7 & $150,667.1$ & 4.631 & 0.118 \\
\hline \multicolumn{6}{|c|}{ Crustaceans } \\
\hline As & 5.818 & 10 & 0.582 & 0.457 & 0.886 \\
\hline $\mathrm{Hg}$ & 0 & 10 & 0 & 0.189 & 0.993 \\
\hline $\mathrm{Cr}$ & 41.25 & 10 & 4.125 & 9.811 & 0 \\
\hline $\mathrm{Pb}$ & 2.704 & 10 & 0.27 & 1.565 & 0.237 \\
\hline $\mathrm{Zn}$ & $119,718.8$ & 10 & $11,971.88$ & 2.428 & 0.081 \\
\hline \multicolumn{6}{|c|}{ Fish } \\
\hline As & 111.747 & 26 & 4.298 & 0.583 & 0.843 \\
\hline $\mathrm{Hg}$ & 0.018 & 26 & 0.001 & 3.844 & 0.05 \\
\hline $\mathrm{Cr}$ & 594.492 & 26 & 22.865 & 0.323 & 0.98 \\
\hline $\mathrm{Pb}$ & 90.464 & 26 & 3.479 & 11.134 & 0.003 \\
\hline $\mathrm{Zn}$ & $420,978.8$ & 26 & $16,191.49$ & 149.202 & 0 \\
\hline
\end{tabular}

*Df: degree of freedom. 


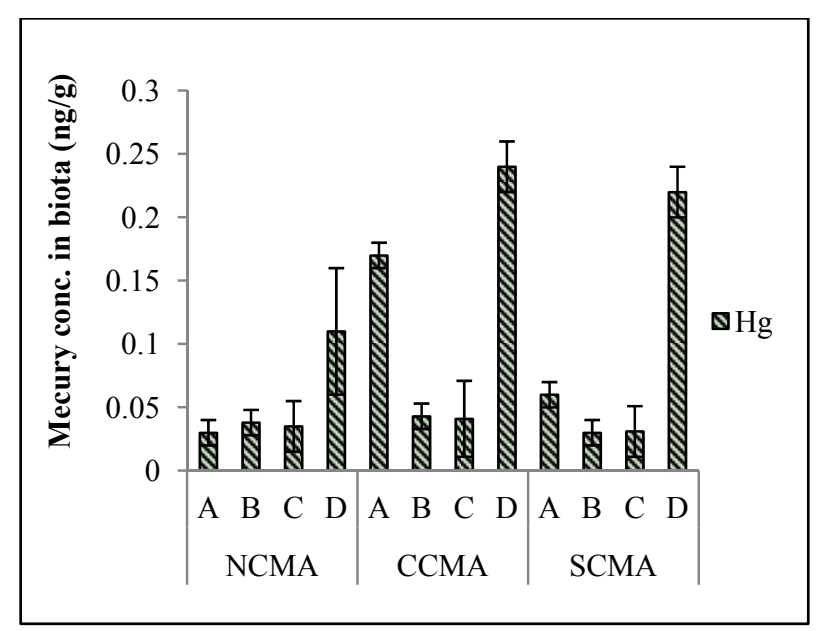

Fig. 3 Concentration (mean $\pm \mathrm{SD}$ ) of $\mathrm{Hg}$ in $\mathrm{A}=$ macroalgae; $B=$ bivalves; $C=$ crustaceans; and $D=$ fish from the NCMAs, CCMAs and SCMAs.

Table 4 The average concentrations of trace metals in fish as recommended by the FAO [36].

\begin{tabular}{lllllll}
\hline Specie & Unit & $\mathrm{Pb}$ & $\mathrm{Zn}$ & $\mathrm{Cr}$ & $\mathrm{Hg}$ & $\mathrm{As}$ \\
\hline Fish & $\mu \mathrm{g} / \mathrm{g}$ w.w. & 2 & 50 & 1 & 0.5 & 1.4 \\
\hline
\end{tabular}

$0.00 \mu \mathrm{g} / \mathrm{g}$ ) was found in the U. petrusa from the Dar es Salaam port area (Fig. 2). Bivalves from the CCMAs had relatively higher concentrations of $\mathrm{Hg}$ $(0.04 \pm 0.02 \mu \mathrm{g} / \mathrm{g})$ compared to the concentration $(0.04 \pm 0.01 \mu \mathrm{g} / \mathrm{g})$ in NCMAs and concentration $(0.03$ $\pm 0.01 \mu \mathrm{g} / \mathrm{g}$ ) in SCMAs. There was significant difference (ANOVA $\mathrm{p}<0.05, \mathrm{~F}=1.223$ ) in $\mathrm{Hg}$ contents in bivalves collected from the three main coastal locations (Table 3). The highest concentration of $\mathrm{Hg}(0.06 \pm 0.03 \mu \mathrm{g} / \mathrm{g})$ was found in A. arcuatula from Mzinga Creek, while the lowest concentration $(0.02 \pm 0.01 \mu \mathrm{g} / \mathrm{g})$ was found in Crassostrea $s p$. from Ruvuma river estuary (Fig. 3).

The results show that crustaceans from the CCMAs had almost similar concentrations of $\mathrm{Hg}(0.04 \pm 0.02$ $\mu \mathrm{g} / \mathrm{g})$ with NCMAs. Lower concentration $(0.03 \pm 0.01$ $\mu \mathrm{g} / \mathrm{g}$ ) was found in SCMAs. There was significant difference (ANOVA $\mathrm{p}<0.05, \mathrm{~F}=0.189$ ) in $\mathrm{Hg}$ contents in crustaceans collected from the three coastal locations (Table 3). Higher concentration of $\mathrm{Hg}(0.05 \pm 0.03 \mu \mathrm{g} / \mathrm{g})$ was found in the crab $P$. pelagicus from Dar es Salaam port and Tanga port areas and in the crab $S$. serrata from the estuaries of
Wami and Ruvu rivers. Lower concentration of $\mathrm{Hg}$ $(0.02 \pm 0.01 \mu \mathrm{g} / \mathrm{g})$ was found in the shrimp P. indicus from stations 1, 3, 7, 10 and 11 (Fig. 4). Like crustaceans, fish species from CCMAs had almost similar concentrations of $\mathrm{Hg}(0.05 \pm 0.03 \mu \mathrm{g} / \mathrm{g})$ as those from SCMAs $(0.05 \pm 0.02 \mu \mathrm{g} / \mathrm{g})$. The lower concentration $(0.04 \pm 0.01 \mu \mathrm{g} / \mathrm{g})$ was reported in NCMAs (Fig. 4). There was significant difference (ANOVA $\mathrm{p}<0.05, \mathrm{~F}=3.844$ ) in $\mathrm{Hg}$ contents in the fish species collected from the three coastal locations (Table 3). Higher concentration of $\mathrm{Hg}(0.08 \pm 0.03$ $\mu \mathrm{g} / \mathrm{g}$ ) was found in the carnivorous fish L. lentjan from Msimbazi river estuary and also in the tissues of an omnivorous fish $A$. dussumieri from Matandu river estuary (Fig. 5). The lowest concentration $(0.01 \pm 0.00$ $\mu \mathrm{g} / \mathrm{g}$ ) was found in the herbivorous fish $S$. ghobban from Tanga port area, planktivorous fish $\mathrm{H}$. kelee from Ruvu river estuary, planktivorous fish $S$. albella from Matandu river estuary and in the detritivorous fish $V$. seheli from Ruvuma river estuary (Fig. 4). Hg concentrations in fish were compared with quality guidelines values FAO [36] and they all were below permissible limits of $0.5 \mu \mathrm{g} / \mathrm{g}$ w.w. (Table 4).

\subsubsection{Chromium}

The highest concentration of chromium was found in the macroalgae samples $(23.67 \pm 8.19 \mu \mathrm{g} / \mathrm{g})$ from the CCMAs of Tanzania. An intermediate concentration $(12.00 \pm 4.56 \mu \mathrm{g} / \mathrm{g})$ was found in the NCMAs of Tanzania, while lowest concentration $(3.75 \pm 1.81 \mu \mathrm{g} / \mathrm{g})$ was found in the samples from the SCMAs of Tanzania (Fig. 3). These concentrations were statistically different across the three coastal locations (ANOVA, $\mathrm{p}<0.05, \mathrm{~F}=5.778$ ) (Table 3). The maximum concentration of $\mathrm{Cr}(45.50 \pm 6.38 \mu \mathrm{g} / \mathrm{g})$ was found in the $U$. petrusa from Dar es Salaam port area, while the lowest concentration $(2.00 \pm 0.03 \mu \mathrm{g} / \mathrm{g})$ was found in the Chaetomorpha sp. from Ruvuma river estuary (Fig. 2). The bivalves from the NCMAs had relatively higher concentration of $\mathrm{Cr}(11.13 \pm 5.25$ $\mu \mathrm{g} / \mathrm{g})$ compared to $7.40 \pm 2.14 \mu \mathrm{g} / \mathrm{g}$ and $5.00 \pm 1.01$ $\mu \mathrm{g} / \mathrm{g}$ recorded in from SCMAs and CCMAs 
respectively (Fig. 3). Although there was significant difference in mean $\mathrm{Cr}$ contents in molluscan bivalves collected from the three coastal locations (ANOVA, $p$ $<0.05, \mathrm{~F}=2.153$ ), within site comparison revealed that higher concentration $(21.00 \pm 9.19 \mu \mathrm{g} / \mathrm{g})$ was found in $S$. cuculata from Mtwara port area while lower concentrations $(2.00 \pm 0.42 \mu \mathrm{g} / \mathrm{g})$ were found in the tissues of the A. arcuatula and Crassostrea $s p$. from Mzinga Creek and Ruvuma river estuaries respectively (Fig. 3 and Table 3). Crustaceans from the SCMAs had relatively higher concentrations of $\mathrm{Cr}$ $(3.10 \pm 0.88 \mu \mathrm{g} / \mathrm{g})$ compared to $3.00 \pm 1.14 \mu \mathrm{g} / \mathrm{g}$ in samples from CCMAs and $2.25 \pm 1.33 \mu \mathrm{g} / \mathrm{g}$ in samples from NCMAs. There was no significant difference (ANOVA $\mathrm{p}>0.05$ ) in $\mathrm{Cr}$ contents in crustaceans collected from the three coastal marine areas (Table 3). The highest concentration of $\mathrm{Cr}(8.00$ $\pm 3.17 \mu \mathrm{g} / \mathrm{g}$ ) was found in the shrimp P. indicus from Mtwara port area, while the lowest concentration $(1.00 \pm 0.02 \mu \mathrm{g} / \mathrm{g})$ was found in the crab S. serrata from Rufiji river estuary (Fig. 4). Results further elucidate that fish species from the NCMAs accumulated relatively higher $\mathrm{Cr}(5.50 \pm 0.19 \mu \mathrm{g} / \mathrm{g})$ compared to values recorded in fish species from CCMAs $(4.80 \pm 0.61 \mu \mathrm{g} / \mathrm{g})$ and SCMAs $(2.30 \pm 0.13$ $\mu \mathrm{g} / \mathrm{g})$. There was significant difference in $\mathrm{Cr}$ contents in the fish species collected from the three coastal locations (ANOVA $\mathrm{p}<0.05, \mathrm{~F}=0.323$ ) (Table 3). The highest concentration of $\mathrm{Cr}(14.50 \pm 5.13 \mu \mathrm{g} / \mathrm{g})$ was found in the carnivorous fish L. lentjan collected from Mzinga Creek, while the lowest concentration $(1.00 \pm 0.02 \mu \mathrm{g} / \mathrm{g})$ was found in the detritivorous fish L. macrolepis from Rufiji river estuary and herbivorous fish S. sutor from Dar es Salaam port area (Fig. 5). Cr concentrations in fish were compared with quality guidelines values FAO [36] and they all were below permissible limits of $1.0 \mu \mathrm{g} / \mathrm{g}$ w.w. (Table 4).

\subsubsection{Lead}

The mean concentration of lead in macroalgae samples was highest $(2.75 \pm 0.52 \mu \mathrm{g} / \mathrm{g})$ in samples from the NCMAs of Tanzania, followed by the

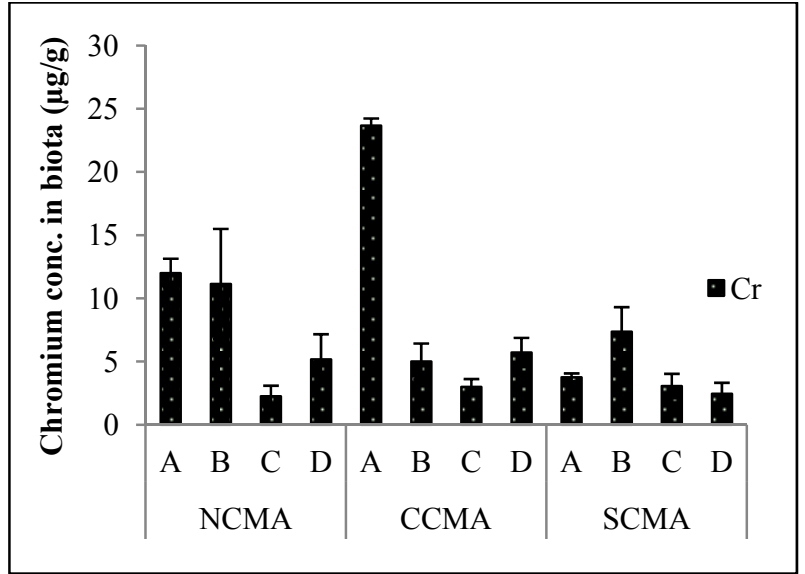

Fig. 4 Concentration (mean \pm SD) of $\mathrm{Cr}$ in $\mathrm{A}=$ macroalgae; $B=$ bivalves; $C=$ crustaceans; and $D=$ fish from NCMAs, CCMAs and SCMAs.

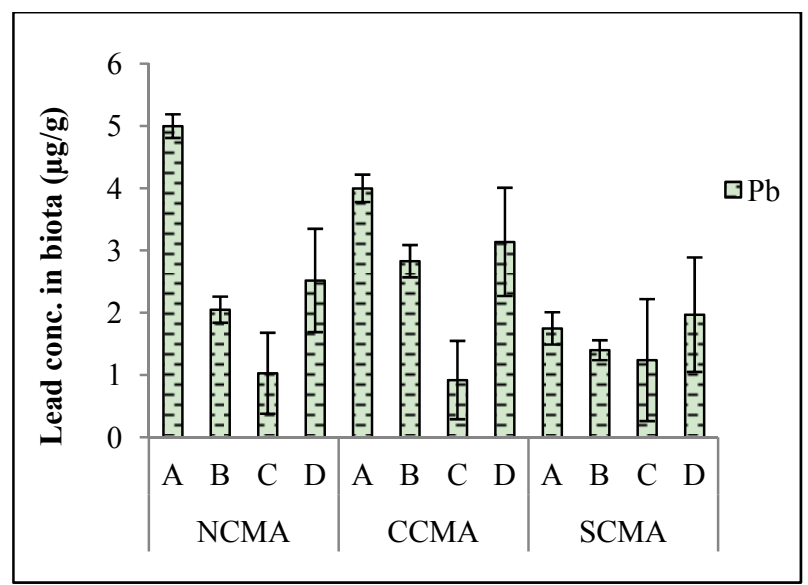

Fig. 5 Concentration (mean $\pm \mathrm{SD}$ ) of $\mathrm{Pb}$ in $\mathrm{A}=$ macroalgae; $B=$ bivalves; $C=$ crustaceans; and $D=$ fish from NCMAs, CCMAs and SCMAs.

CCMAs $(1.37 \pm 0.18 \mu \mathrm{g} / \mathrm{g})$ and $1.15 \pm 0.26 \mu \mathrm{g} / \mathrm{g}$ in samples from the SCMAs of Tanzania (Fig. 2). Significant difference existed in mean $\mathrm{Pb}$ concentrations of macroalgae samples collected from the three coastal locations (ANOVA $\mathrm{p}<0.05, \mathrm{~F}=$ 0.402), (Table 3). Maximum concentration of $\mathrm{Pb}$ (5.50 $\pm 1.08 \mu \mathrm{g} / \mathrm{g}$ ) was found in S. asperifolium from Ruvu river estuary, while the minimum concentration of the metal $(0.10 \pm 0.02 \mu \mathrm{g} / \mathrm{g})$ was measured in the $U$. petrusa from Dar es Salaam port area. The results also show that bivalves from the CCMAs had relatively higher concentrations of $\mathrm{Pb}(2.83 \pm 0.86 \mu \mathrm{g} / \mathrm{g})$ compared to bivalves from NCMAs $(2.05 \pm 0.93 \mu \mathrm{g} / \mathrm{g})$ and SCMAs $(1.40 \pm 0.65 \mu \mathrm{g} / \mathrm{g})$. Significant difference 
was found in $\mathrm{Pb}$ contents in molluscan bivalves across the three coastal locations (ANOVA $\mathrm{p}<0.05, \mathrm{~F}=$ 3.201). Highest concentration of $\mathrm{Pb}(5.00 \pm 1.17 \mu \mathrm{g} / \mathrm{g})$ was found in Crassostrea $s p$. from Pangani river estuary and lower values $(0.50 \pm 0.02 \mu \mathrm{g} / \mathrm{g})$ was measured in Crassostrea $s p$. form Tanga port area (Fig. 5). Crustaceans from the SCMAs had relatively higher concentrations of $\mathrm{Pb}(1.24 \pm 0.52 \mu \mathrm{g} / \mathrm{g})$ compared to crustaceans collected from NCMAs $(1.03$ $\pm 0.46 \mu \mathrm{g} / \mathrm{g})$ and CCMAs $(0.92 \pm 0.31) \mu \mathrm{g} / \mathrm{g}$ (Fig. 3). Statistical results revealed significant difference in $\mathrm{Pb}$ content of crustacean tissues across the three sampled coastal marine areas (ANOVA $\mathrm{p}<0.05, \mathrm{~F}=1.565$ ). Higher concentration of $\mathrm{Pb}(1.80 \pm 0.39 \mu \mathrm{g} / \mathrm{g})$ was measured in the crab $P$. pelagicus from Ruvuma river estuary while the shrimp $P$. indicus from Wami river estuary, Ruvuma river estuary and Mtwara port area; and the crab $S$. serrata from Wami river estuary and $P$. pelagicus from Mzinga Creek recorded lower concentration $(0.50 \pm 0.02 \mu \mathrm{g} / \mathrm{g})$ of lead (Fig. 4). Results further reveal that fish species from the CCMAs had relatively higher average concentrations of $\mathrm{Pb}(2.60 \pm 1.32 \mu \mathrm{g} / \mathrm{g})$ compared to $2.33 \pm 0.98 \mu \mathrm{g} / \mathrm{g}$ from SCMAs and $2.29 \pm 1.05 \mu \mathrm{g} / \mathrm{g}$ from NCMAs. These results were statistically significant different across the three coastal marine locations (ANOVA $\mathrm{p}<$ $0.05, \mathrm{~F}=11.134)$. The highest concentration of $\mathrm{Pb}$ $(8.00 \pm 3.07 \mu \mathrm{g} / \mathrm{g})$ was measured in the carnivorous $L$. lentjan from Dar es Salaam port area, while the lowest concentration $(0.50 \pm 0.12 \mu \mathrm{g} / \mathrm{g})$ was found in the herbivorous $S$. ghobban from Tanga port area, the planktivorous $S$. albella from the estuaries of Wami and Ruvu rivers, the detritivorous L. macrolepis and $V$. seheli from the estuaries of Rufiji and Ruvuma rivers respectively (Fig. 5). $\mathrm{Pb}$ concentrations in fish were compared with quality guidelines values FAO [36] and they all were below permissible limits of $2.0 \mu \mathrm{g} / \mathrm{g}$ w.w. (Table 4).

\subsubsection{Zinc}

The average concentration of zinc in macroalgae samples was highest $(111.50 \pm 5.17 \mu \mathrm{g} / \mathrm{g})$ in samples from NCMAs followed by SCMAs $(60.63 \pm 3.53 \mu \mathrm{g} / \mathrm{g})$ and $51.00 \pm 1.26 \mu \mathrm{g} / \mathrm{g}$ in samples from CCMAs. These results illustrate similar distribution of this metal across the three coastal marine areas (ANOVA $\mathrm{p}<0.05, \mathrm{~F}=0.280$ ) (Table 3). Inter-site comparison show that highest concentration of $\mathrm{Zn}(216.00 \pm 11.66$ $\mu \mathrm{g} / \mathrm{g}$ ) was found in S. asperifolium from Ruvu river estuary, while the lowest concentration $(23.50 \pm 8.93$ $\mu \mathrm{g} / \mathrm{g}$ ) was measured in the U. fasciata from Pangani river estuary (Fig. 2). The bivalves from the CCMAs recorded higher concentrations of $\mathrm{Zn}(616.50 \pm 21.14$ $\mu \mathrm{g} / \mathrm{g}$ ) compared to $167.30 \pm 16.85 \mu \mathrm{g} / \mathrm{g}$ from NCMAs and $116.1 \pm 18.22 \mu \mathrm{g} / \mathrm{g}$ from SCMAs. There was no significant difference (ANOVA $\mathrm{p}>0.05, \mathrm{~F}=4.631$ ) in $\mathrm{Zn}$ contents in molluscan bivalves collected from the three coastal locations (Table 3). The highest concentration of $\mathrm{Zn}(651.00 \pm 6.51 \mu \mathrm{g} / \mathrm{g})$ was measured in Crassostrea sp. from Msimbazi river estuary, while the lowest concentration $(29.50 \pm 7.93$ $\mu \mathrm{g} / \mathrm{g}$ ) was found in S. cucullata from Mtwara port area (Fig. 3).

Crustaceans from the NCMAs had relatively higher concentrations of $\mathrm{Zn}(165.90 \pm 33.39 \mu \mathrm{g} / \mathrm{g})$ compared to the concentration $(65.10 \pm 15.16 \mu \mathrm{g} / \mathrm{g})$ in CCMAs and the lowest concentration $(52.00 \pm 22.16 \mu \mathrm{g} / \mathrm{g})$ in samples from SCMAs. There was significant difference (ANOVA $\mathrm{p}<0.05, \mathrm{~F}=2.428$ ) in $\mathrm{Zn}$ content in crustaceans collected from the three coastal locations (Table 2). The highest concentration of $\mathrm{Zn}(411.50 \pm$ $13.04 \mu \mathrm{g} / \mathrm{g}$ ) was found in the crab $P$. pelagicus from Pangani river estuary, while the lowest concentration $(28.00 \pm 4.34 \mu \mathrm{g} / \mathrm{g})$ was measured in the shrimp $P$. indicus from Mtwara port area (Fig. 4). The results show that fish species from the SCMAs had higher mean concentration of $\mathrm{Zn}(101.10 \pm 21.16 \mu \mathrm{g} / \mathrm{g})$ compared to NCMAs $(84.00 \pm 15.03 \mu \mathrm{g} / \mathrm{g})$ and CCMAs $(61.40 \pm 19.82 \mu \mathrm{g} / \mathrm{g})$. There was no significant difference (ANOVA $\mathrm{p}>0.05$ ) in mean $\mathrm{Zn}$ contents in the fish species collected from the three coastal marine areas (Table 3). The highest concentration of $\mathrm{Zn}$ $(667.00 \pm 43.11 \mu \mathrm{g} / \mathrm{g})$ was measured in the omnivorous 


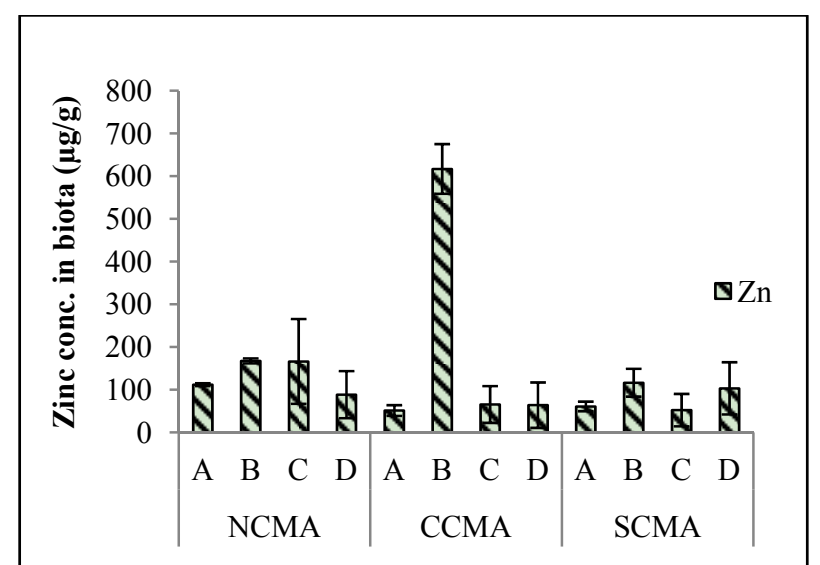

Fig. 6 Concentration (mean \pm SD) of $\mathrm{Zn}$ in $\mathrm{A}=$ macroalgae; $B=$ bivalves; $C=$ crustaceans; and $D=$ fish from NCMAs, CCMAs and SCMAs.

fish A. dussumieri from Matandu river estuary, while the lowest concentration $(17.00 \pm 9.48 \mu \mathrm{g} / \mathrm{g})$ was found in the zoobenthivorous fish $P$. quadrilineatus from Mtwara port area (Fig. 6). Zn concentrations in fish were compared with quality guidelines values FAO [36] and they all were below permissible limits of $50.0 \mu \mathrm{g} / \mathrm{g}$ w.w. (Table 4).

\subsection{The TPs of A. dussumieri and L. lentjan}

The estimation of the positions of the cat fish $A$. dussumieri and the emperor L. lentjan. in the estuarine and nearshore waters of Tanzania was made using the stable $\mathrm{C}$ and $\mathrm{N}$ isotope results. The $\mathrm{TP}$ of fishes $\left(\mathrm{TP}_{\mathrm{SIA}}\right)$, was calculated following the procedure of Cabana, G. and Rasmussen, J. B. [37] using Eq. (1):

$$
T P_{S I A}=\left[\left(\text { Fish } \delta^{15} N-\text { Primary consumer } \delta^{15} N\right) / 3.4\right]+2
$$

Primary consumer $\delta^{15} \mathrm{~N}$ was calculated as the mean $\delta^{15} \mathrm{~N}$ of all primary consumers (i.e., filter feeder, collector, gatherer, shredder and grazer taxa) collected for a sampling event. Trophic guilds were assigned using the literature [38]. Stomach contents analysis also enabled the determination of TP of $A$. dussumieri and L. lentjan. By using gut content analysis, the TP of fish $\left(\mathrm{TP}_{\mathrm{GCA}}\right)$ was also calculated according to the method of Vander-Zanden, M. J., et al. [39] using Eq. (2):

$$
T P_{G C A}=\sum(P i * T i)
$$

Where $P_{i}$ is proportion of the $\mathrm{i}^{\text {th }}$ food item and $T_{i}$ is TP of each food item. TPs of food items were based on literature dietary data [39, 40]. According to Lopez-Fernandez, H. and Winemiller, K. O. [38], in marine systems there are: algae at the bottom of the food web ( $\mathrm{TL}=1$, by definition); herbivorous zooplankton feeding on the algae $(\mathrm{TL}=2)$; large zooplankton or small fishes, feeding on the herbivorous zooplankton ( $\mathrm{TL}=3$ ); large fishes (for example, cod, tuna and groupers) whose food tends to be a mixture of low-TP and high-TP organisms $(\mathrm{TL}=$ 3.5-4.5).

The stable nitrogen isotopic signatures results show that A. dussumieri and L. lentjan from all sampling stations belong to the TL of the secondary consumers. The estimated TP based on the stable isotopes of carbon and nitrogen based on the procedure of Cabana, G. and Rasmussen, J. B. [37] for A. dussumieri was 3.5 and that of L. Lentjan was 3.0. Individuals of $A$. dussumieri and L. lentjan increased in weight linearly, as their length increased. These findings are in agreement with the TP of marine fishes as estimated using $\delta^{15} \mathrm{~N}$ values [41]. Cabana, G. and Rasmussen, J. B. [37] reported a linear relationship between the size of individuals of benthic assemblages and their stable nitrogen isotope values. The good agreement between the determination of the TLs of 3.5 and 3.0 for $A$. dussumieri (Fig. 7) and L. lentjan (Fig. 8) respectively by using $\delta^{15} \mathrm{~N}$ method and the traditional approach of using the gut-content analysis supports the application of an average trophic enrichment of 3.4\% between successive TL in the estimation of TPs of consumers as suggested by Vander-Zanden, M. J. and Rasmussen, J. B. [42].

\subsection{Trophic Transfer of Heavy Metals along the Food} Chains

The stable isotopes of $\mathrm{C}$ and $\mathrm{N}\left(\delta^{13} \mathrm{C}\right.$ and $\left.\delta^{15} \mathrm{~N}\right)$ for the A.dussumieri and L. lentjan and their TLs were used in the investigation of trophic transfers of heavy metals along their food chains. 


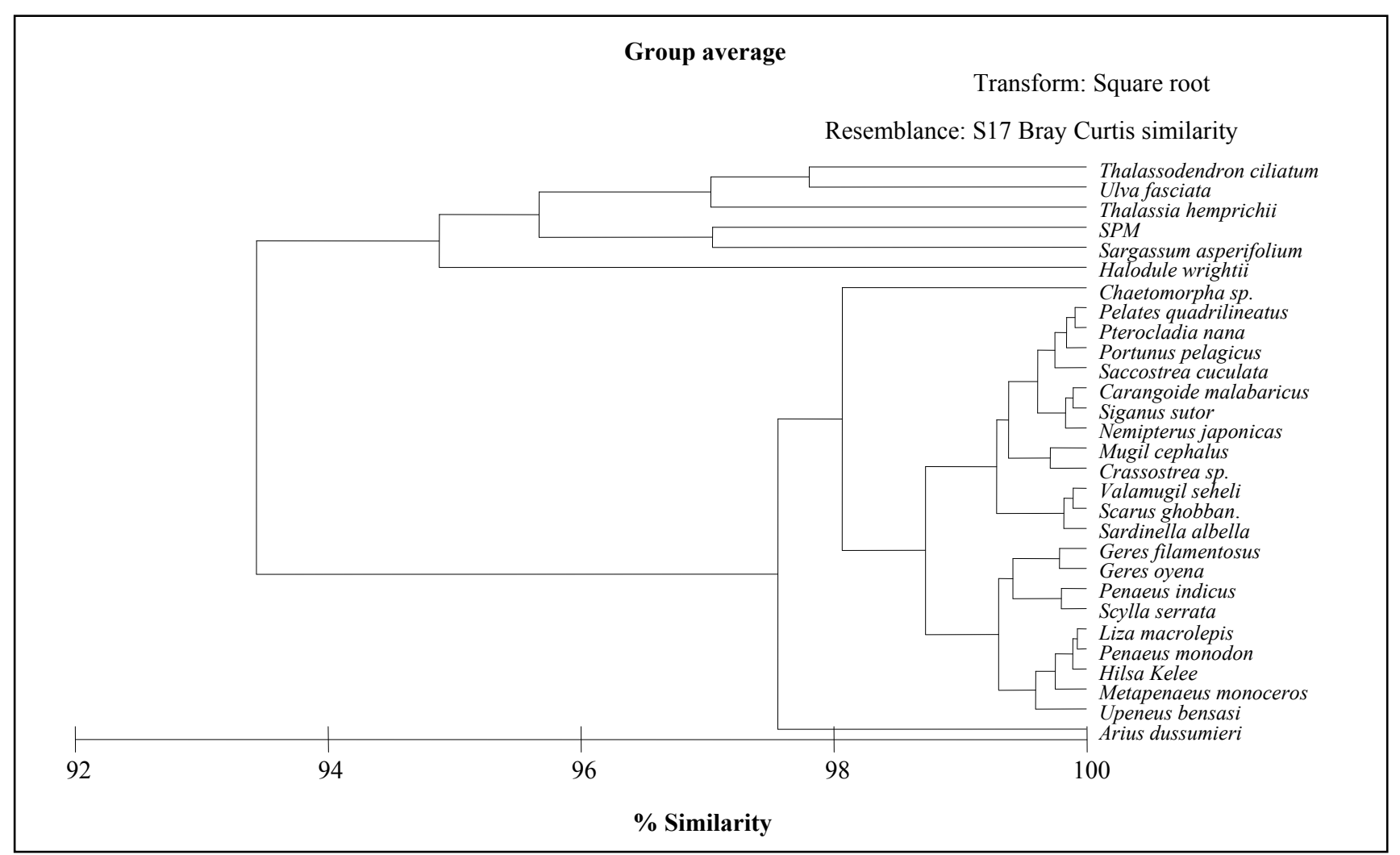

Fig. 7 Relationship between $\delta^{15} \mathrm{~N}$ and log-transformed $\mathrm{Hg}$ concentration in fish from Tanzanian coastal marine environment.

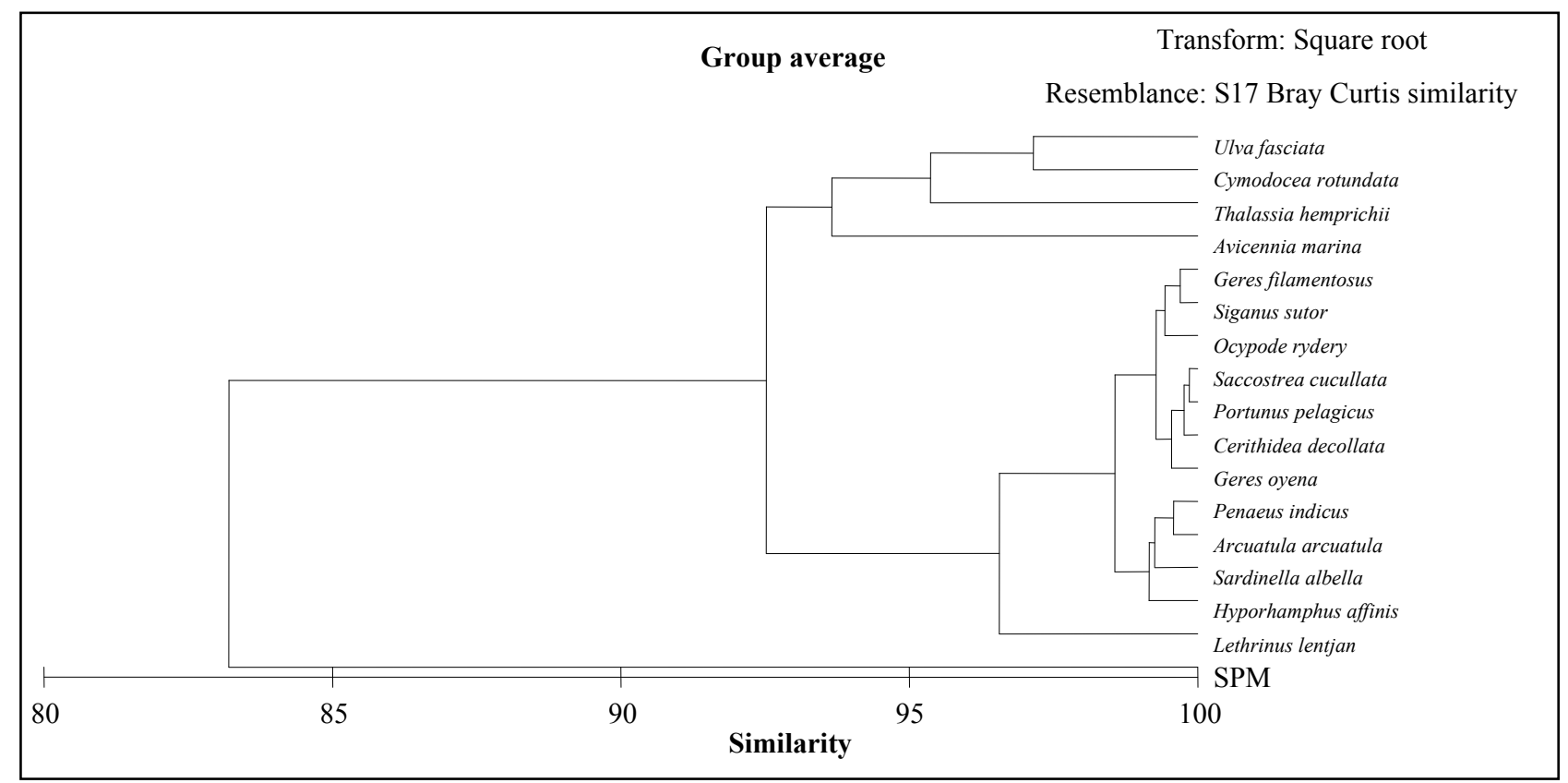

Fig. 8 Relationship between $\delta^{15} \mathrm{~N}$ and log-transformed Pb concentration in fish from Tanzanian coastal marine environment. 

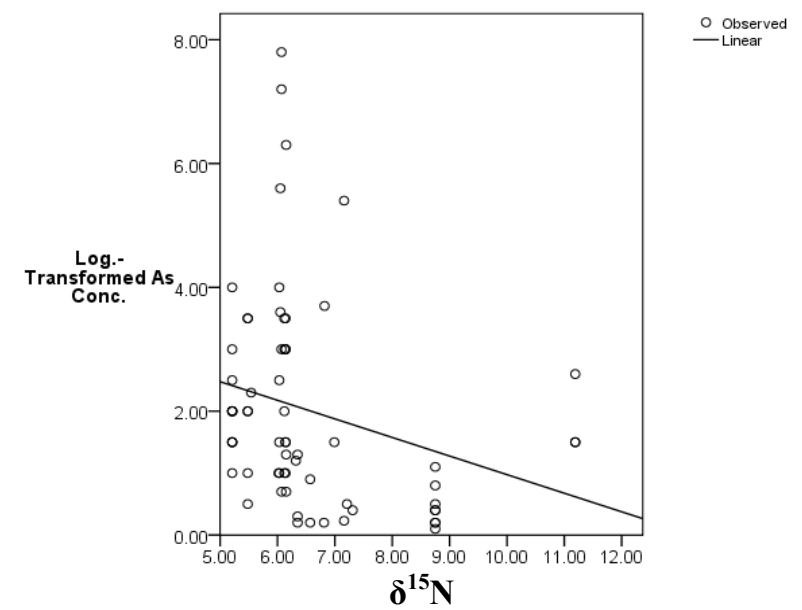

Fig. 9 Relationship between $\delta^{15} \mathrm{~N}$ and log-transformed As concentration in fish from Tanzanian coastal marine environment.

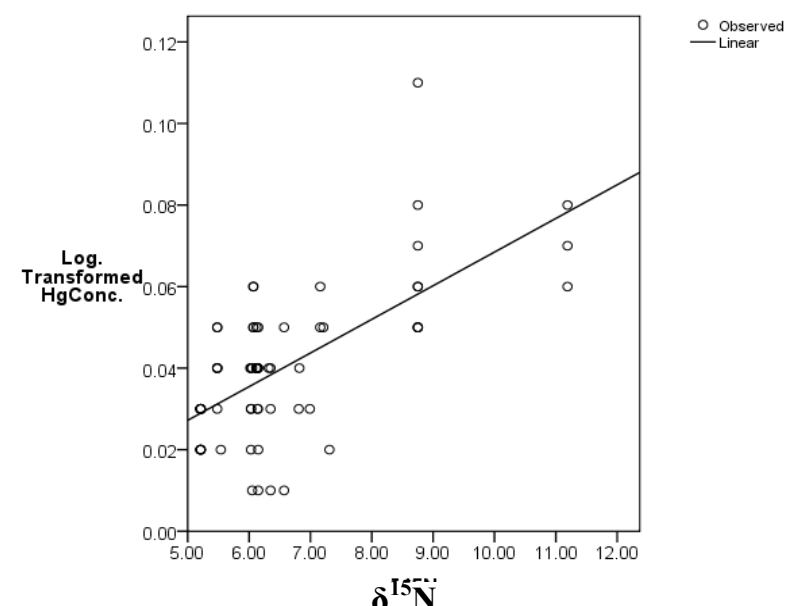

Fig. 10 Relationship between $\delta^{1\lrcorner} N$ and log-transformed $\mathrm{Hg}$ concentration in fish from Tanzanian coastal marine environment.

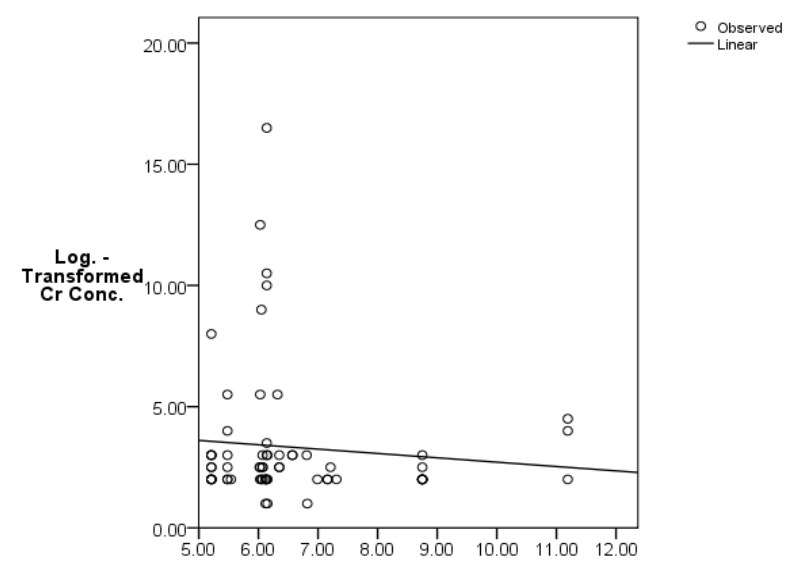

Fig. 11 Relationship between $\delta^{15} N$ and log-transformed Cr concentration in fish from Tanzanian coastal marine environment.

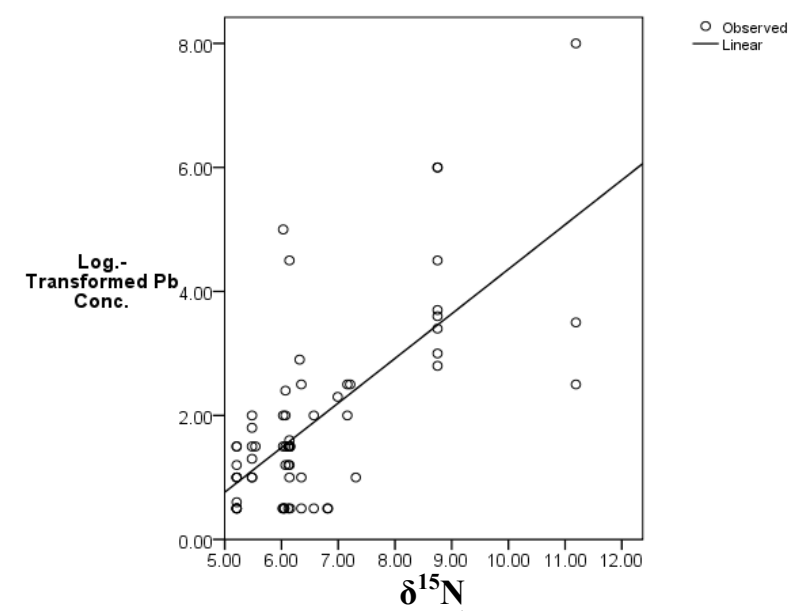

Fig. 12 Relationship between $\delta^{15} \mathrm{~N}$ and log-transformed $\mathrm{Pb}$ concentration in fish from Tanzanian coastal marine environment.

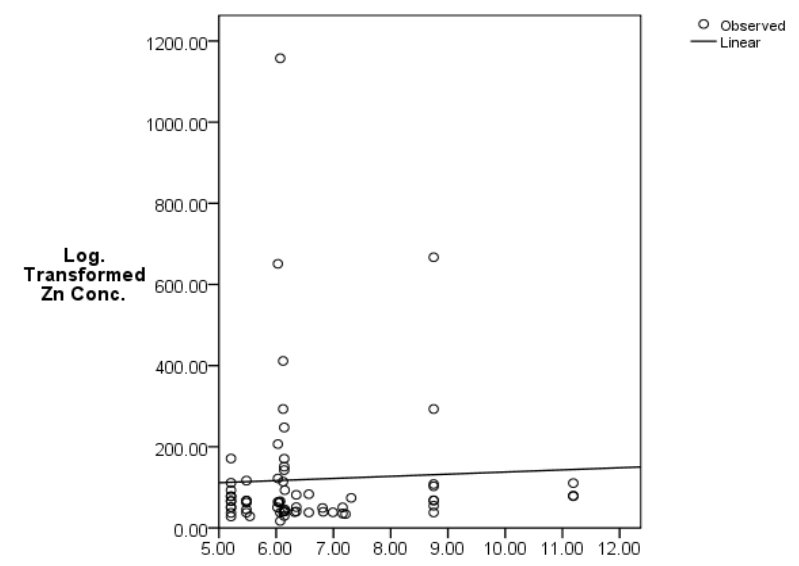

$$
\delta^{15} \tilde{N}^{-2 \cdot}
$$

Fig. 13 Relationship between $\delta^{1, N}$ and log-transformed Zn concentration in fish from Tanzanian coastal marine environment.

In the A. dussumieri and L. lentjan food chains, log concentrations of mercury and lead in muscle and soft tissues of animal samples were found to increase significantly $(p=0.05$ and $p=0.01)$ with increasing TLs (Figs. 9 and 10). The slopes for these elements were 0.368 for log-transformed $\mathrm{Hg}$ and 0.246 for log-transformed $\mathrm{Pb}$. Regressions for $\log \mathrm{As}$ and $\mathrm{Cr}$ were significant, with a negative slope of -0.068 and -0.005 respectively (Figs. 11 and 12). Non-significant slope was found for $\mathrm{Zn}$, indicating that this element neither biomagnifies nor biodilutes through the food web (Fig. 13).

There was a linear relationship between 
log-transformed $\mathrm{Hg}$ and $\mathrm{Pb}$ concentrations with $\delta^{15} \mathrm{~N}$ values for biota analysed. The slope of regression line was negative between log-transformed $\mathrm{As}$ and $\mathrm{Cr}$ concentrations with $\delta^{15} \mathrm{~N}$ values, while completely flat regression line was between log-transformed $\mathrm{Zn}$ concentration with $\delta^{15} \mathrm{~N}$ values for biota. The steeper slope was observed between log-transformed $\mathrm{Hg}$ with $\delta^{15} \mathrm{~N}$ in biota as compared to the slope for $\mathrm{Pb}$.

\section{Discussion}

4.1 Accumulation and Biomagnification of Heavy Metals along Food Chains of A. dussumieri and L. lentjan

\subsubsection{Arsenic}

Bioaccumulation of As was high in macroalgae from NCMAs followed by SCMAs and the last was CCMAs. Although As was not detected in the water samples, it was found to bioaccumulate in the three species of macroalgae. The significant BCF for As in the macroalgae $S$. asperifolium in Ruvu river estuary and U. fasciata in Msimbazi Creek was expected because of the high concentration of the As in the sediments from the stations. Higher BCF for As in $U$. fasciata from Wami river estuary could be due to high ability of Ulva $s p$. to accumulate arsenic from the environment as compared to other species of macroalgae in other stations. This idea is complemented by discussion given by Thomson, D., et al. [43] who reported that arsenic concentration and which are important primary producer in marine food chains. Rahman, M. A., et al. [44] reported that total arsenic concentrations varied between classes of algae, and significant differences between algae classes and habitats were found for the proportion of As species.

Bioaccumulation of arsenic in bivalves was generally low. The only significant BAF was found in S. cucullata in Mtwara port area $(\mathrm{BAF}=133)$ in SCMAs. The results show that no significant BAF was found in crustaceans from NCMAs, CCMAs and also from SCMAs. The findings are in agreement with the previous report by Barwick, M. and Maher, W. [45] which had reported that As and arsenic-containing organic compounds did not accumulate to a great extent in aquatic organisms due to its highly toxic nature.

The results on As bioaccumulation in fish showed that the metal had relatively high BAF in the fish from CCMAs, followed by SCMAs and then NCMAs. Only five fish species were found with significant BAF showing that they accumulate As from the environment. These fish species include the herbivorous S. sutor from Msimbazi river estuary $(\mathrm{BAF}=108)$, the zoobenthivorous $P$. quadrilineatus from Mzinga Creek (BAF $=300)$, the omnivorous $A$. dussumieri from Mtwara port area $(\mathrm{BAF}=183)$, and Wami river estuary $(\mathrm{BAF}=133)$ as well as the zooplanktivorous $S$. albella also from Wami river estuary $(\mathrm{BAF}=109)$. The high BAF for these fish suggests high availability of As at stations 3, 5 and 7 . Hardersen, S. and Wratten, S. D. [46] reported in their research the uptake of As by fish from water, food, sediments and suspended particulate material. Therefore, arsenic present in both water and sediments at these sampling stations was available for uptake by fish. The uptake of sediment-associated contaminants by fish may occur by respiratory and dietary routes, whereas the dermal route is usually a minimal contributor of exposure, due to the often effective barrier provided by the external epithelium [47].

The result of trophic transfer (trophodynamics) of As along A. dussumieri and L. lentjan food chain is described by negative regression which means biodilution of the metal (Fig. 8). The finding was confirmed by the elevated concentrations of arsenic in the macroalgae, macrobenthos and small fish, while larger fish had lower concentrations. Interpretation of this observation is supported by the findings of Wang, W. X. [9] who reported that concentrations of metals decreased at a higher TL in the marine food chain. This is mainly a result of an effective efflux of metals from macrobenthos and a very low assimilation of metals by marine fish. Other researchers have reported 
that arsenic and/or its metabolites is a chemical that bioaccumulates in tissues of aquatic organisms but does not biomagnify, rather it biodilutes in the aquatic food chain [31, 48-50]. Yet Thomson, D., et al [43] report that, dietary exposure to arsenic from aquatic foods would not be a serious problem for humans due to its biodiminution and biotransformation to less toxic organo-As species.

\subsubsection{Mercury}

Results show that bioconcentration of mercury were higher in the macroalgae from CMCAs followed by SCMAs and NCMAs. Bioaccumulation of mercury was higher in the macroalgae than in all other biota analysed, with significant BCFs measured in eight stations out of eleven. Higher significant BCF values were found in $U$. fasciata from Msimbazi river estuary $(1,700)$, in U. petrusa from Dar es Salaam port area (700) and in Chaetomorpha sp. from Rufiji river estuary (900). These results show that Ulva sp. and Chaetomorpha $s p$. have a higher ability to accumulate $\mathrm{Hg}$ from the environment as compared to other macroalgae species. The high BCFs for macroalgae were also related to the sampling stations with higher concentrations of available $\mathrm{Hg}$ in water and sediments. Karez, C. S., et al. [51] reported that high levels of $\mathrm{Hg}$ in the algae reflect the high bioavailability of metals and the capacity of the algae to accumulate metals.

The macrobenthos (bivalves and crustaceans) had generally low BAFs throughout the study area suggesting that most of the macrobenthos accumulate heavy metals from biota they consume. Low BAFs values for this group of organisms could, therefore, be due the use of water and sediments data in computing BAFs. Similar results have been reported by Lee, B. G., et al. [52] that most benthic organisms obtain a large fraction of their contaminants through ingestion and not by direct accumulation from overlying water or pore-water. Similarly, the BAFs for mercury in fish from coastal marine area of Tanzania were low and not significant. These indicative results suggest that at present, fish in the coastal marine areas of Tanzania are not bioaccumulating $\mathrm{Hg}$ from the environment. Low BAFs for $\mathrm{Hg}$ in fish are probably a result of the low concentration of available $\mathrm{Hg}$ in these environments. Romeo, M., et al. [53] observed that the ability of fish to accumulate heavy metals depended on ecological needs, metabolism, and the extent of pollution in sediment, water and food items.

Results on trophic transfer of $\mathrm{Hg}$ along $A$. dussumieri and $L$. lentjan food chains in this study show that biomagnification of $\mathrm{Hg}$ was evidenced by a positive regression results (Fig. 9). This was further confirmed by elevated $\mathrm{Hg}$ concentrations in the big fish, while small fish, macroalgae and macrobenthos had lower concentrations. Regression relationships between $\mathrm{Hg}$ concentrations and $\delta^{15} \mathrm{~N}$ have been discussed in other aquatic food chains $[15,29,30,54$, 55] demonstrating biomagnification of mercury along food chains despite low ambient concentrations of this metal in the environment. Results of this study display similar mechanism of biomagnification of metals from lower TL organisms such as plankton or algae to higher TL organisms such as $A$. dussumieri and $L$. lentjan food webs.

Higher Log.-mercury slope found in this study compared to Log.-lead slope gives evidence that $\mathrm{Hg}$ is the major biomagnifying element in A. dussumieri and L. lentjan food chains from Tanzania coastal marine environment. This means that $\mathrm{Hg}$ is biomagnified through this food webs as evidenced by $\delta^{15} \mathrm{~N}$ regardless of productivity or salinity (marine vs. freshwater) of the ecosystem. This argument is supported by the results reported by Campbell, L. M., et al. [15] who found that MeHg measured by $\delta^{15} \mathrm{~N}$ is biomagnified through diverse food webs, regardless of productivity (eutrophic vs. oligotrophic), latitude (arctic vs. tropical) or salinity (marine vs. freshwater) of the ecosystem.

\subsubsection{Chromium}

The results show that the bioconcentration of chromium was higher in the macroalgae from CCMAs, followed by macroalgae from NCMAs and SCMAs. 
Generally, chromium was found to significantly bioaccumulate in all the analysed species of macroalgae. Significant BCF values for $\mathrm{Cr}$ were found in the $U$. petrusa from Dar es Salaam port area $(1,820)$ and in $U$. fasciata from Wami river estuary $(1,240)$. The high BCFs for macroalgae are in agreement with the high $\mathrm{Cr}$ concentration that was observed in the water samples from the sampling stations. Ulva $s p$. had the highest ability to accumulate $\mathrm{Cr}$ as compared to the other species of macroalgae. The high BCFs are also indicative of the high dissolved $\mathrm{Cr}$ in water samples from Wami river estuary and Dar es Salaam port area. According to Luoma, S. N. [56], unlike other bioindicators of heavy metal contamination such as filter-feeding animals, macroalgae accumulate dissolved metal ions in the waters. Therefore, only heavy metals with high solubility products are expected to have significant BCFs in macroalgae.

The bivalves from NCMAs had high BAFs for chromium, followed by SCMAs and CCMAs. Significant BAFs for $\mathrm{Cr}$ in bivalves were measured only in S. cuculata from Wami river estuary (220), Ruvu river estuary (111) and Mtwara port area (300). Similarly, water samples from CCMAs were found to contain higher particulate chromium as well as higher percentage of available $\mathrm{Cr}$ in the sediment as compared to NCMAs and SCMAs. S. cuculata was found to have high ability to accumulate and store chromium in their tissues as compared to the ability of A. arcuatula. This observation is in agreement with the research data from China in which $S$. cucullata were described as the strongest metal accumulators among bivalve species [57]. The accumulation of chromium by crustaceans from the coastal marine areas of Tanzania was low with no crustacean found having significant BAF. Similarly, there was a low bioaccumulation of $\mathrm{Cr}$ in fish from the studied locations with no fish having significant BAF. It can therefore be suggested that crustaceans and fish do not significantly bioaccumulate chromium from the environment (water and sediment).
The biomagnification results showed that there was a decrease of concentration of $\mathrm{Cr}$ along A. dussumieri and $L$. lentjan food chains (biodilution) which was implied by negative regressions graphs (Fig. 10). The result was further confirmed by the elevated concentrations of $\mathrm{Cr}$ in the macroalgae, macrobenthos and small fish, while larger fish had lower concentrations. It has been reported that concentrations of metals decrease at a higher TL in the marine food chain as a result of an effective efflux of metals from macrobenthos and a very low assimilation of metals by marine fish [9].

\subsubsection{Lead}

Lead is the only heavy metal which has no significant BCF in macroalgae from all the three main sites despite some high $\mathrm{Pb}$ concentrations in sediments from the study area. The low BCFs in the macroalgae are related to the low concentration of lead in the water samples which was largely below the detection limit. It is well known that macroalgae accumulate heavy metals proportional to the surrounding medium [58] and that the accumulation of the heavy metal such as $\mathrm{Pb}$ in macroalgae depends on the factors like metal contents in water, absorption properties of the algae species, and to some extent the metal content of sediment [59].

Bivalves S. cuculata from the estuaries of Rufiji and Matandu rivers (290 and 193, respectively) in SCMAs had significant BAF for lead. Significant BAF was also found in $S$. cuculata from Wami river estuary (133) and Ruvu river estuary (141) in NCMAs. Other bivalves displayed insignificant values for BAF of this metal. On the other hand, sediments from the estuaries of Wami, Ruvu, Rufiji and Matandu rivers had high concentration of available $\mathrm{Pb}$ which possibly has an influence on the observed BAFs. Insignificant BAFs displayed by crustaceans and fish are a clear indication that these species do not substantially bioaccumulate $\mathrm{Pb}$ from the coastal marine areas of Tanzania.

Positive regressions result elucidates that $\mathrm{Pb}$ biomagnifies along A. dussumieri and L. lentjan food 
chains in Tanzanian coastal marine waters (Fig. 11). Elevated $\mathrm{Pb}$ concentrations in the big fish species relative to small fish, macroalgae and macrobenthos displaying lower concentrations of this metal in this study further confirm this observation. Positive regression relationships between $\log _{10}$ transformed $\mathrm{Pb}$ concentrations and $\delta^{15} \mathrm{~N}$ have been used by different authors in deleaniting biomagnification of this metal in aquatic food webs $[12,18,29,30]$. In the present study, the graph (Fig. 11) of log-transformed $\mathrm{Pb}$ slope was lower than that of $\mathrm{Hg}$ indicating that $\mathrm{Hg}$ potentially biomagnifies more than $\mathrm{Pb}$ along $A$. dussumieri and L. lentjan food chains.

\subsubsection{Zinc}

The results show high BCF for zinc in macroalgae from the coastal marine areas of Tanzania. Highly significant BCF values were observed in $S$. asperifolium from Ruvu river estuary $(3,323)$, in Chaetomorpha sp. from Ruvuma river estuary $(1,536)$, U. fasciata from Matandu river estuary $(1,164)$ and in U. fasciata from Wami river estuary $(1,088)$. The high BCFs for macroalgae are consistent with the observed high zinc concentration in the macroalgae. The results also suggest that the macroalgae have a high ability of bioaccumulating zinc in the tissue.

The bioaccumulation of $\mathrm{Zn}$ was also high in bivalves from all sites. The significant BAFs were found in A. arcuatula from Mzinga Creek $(1,630)$ and S. cuculata from the estuaries of Ruvu, Wami and Rufiji rivers (307, 204 and 187, respectively). The high values of BAFs relates well with the concentration of $\mathrm{Zn}$ in the suspended particulate matter which was higher at Mzinga Creek and Rufiji river estuary. Similarly, higher concentrations of available zinc in sediments were found at the estuaries of Msimbazi, Rufiji and Ruvu rivers. The current study argues that bivalves have high ability to accumulate zinc, and that molluscan life processes do not seem to be affected by excess zinc which is frequently accumulated far in excess of the organism's immediate needs [60].
The bioaccumulation of zinc in crustaceans from the coastal marine areas of Tanzania was high. The significant BAF was observed in the $P$. indicus and $P$. pelagicus from Mtwara port area, in $P$. indicus and $P$. pelagicus from Ruvuma river estuary and in $P$. indicus and S. serrata from Rufiji river estuary. However, there was no crustacean with significant BAF from NCMAs, probably due to the lower values of available $\mathrm{Zn}$ in the sediment from NCMAs. A study by Romeo, M., et al. [61] discusses that $\mathrm{Zn}$ can be taken up and accumulated in tissues and bodies of many species of marine invertebrates to concentrations usually much higher than concentrations in the surrounding seawater or sediments.

Only four fish species were found to accumulate zinc in their tissues to a significant extent from the coastal marine areas of Tanzania. The significant BAF was observed in the omnivorous A. dussumieri from the estuaries of Matandu, Ruvu and Wami rivers (733, 364 and 146, respectively) and Mtwara port area (143). The observed significant BAF of $\mathrm{Zn}$ in the catfish $A$. dussumieri from all sites was probably due to the feeding habit. Previous studies [62, 63] have reported that variability of levels of metals such as $\mathrm{Zn}$ in different fish species is a function of feeding habits, ecological needs, metabolism or age, size and length of the fish and their habitats, which affirms the argument.

Zinc trophodynamic results are explained by positive regression slope and confirmed by evenly distribution of $\mathrm{Zn}$ in macroalgae, macrobenthos and fish. The results clarify that $\mathrm{Zn}$ concentrations did not increase or decrease with TLs along A. dussumieri and L. lentjan food chains (Fig. 12). Zinc is an essential element with many important metabolic functions which necessitates most organisms to have biochemical mechanisms to regulate the amount of $\mathrm{Zn}$ in their cells [63]. Campbell, L. M., et al. [15], suggested that the rate of $\mathrm{Zn}$ excretion would be relative to $\mathrm{Zn}$ ingestion, thereby ensuring a relatively constant concentration in biota throughout the food web. 


\section{Conclusion}

This study revealed evidently the slight biomagnification of heavy metals mercury $(\mathrm{Hg})$ and lead $(\mathrm{Pb})$ in fish tissues collected from the coastal marine areas of Tanzania. Therefore, a regular monitoring of heavy metal levels in fishes is necessary. Despite these observations, heavy metal levels in fish muscles in this study were generally below the permissible limits suggested by FAO [36] and posed no threat to public health yet.

\section{Reference}

[1] Kravitz, M., Kroner, S., and Boethling, R. 2000. Bioaccumulation Testing and Interpretation for the Purpose of Sediment Quality Assessment: Status and Needs. Report no: EPA-823-R-00-001, US Environmental Protection Agancy (EPA), Washington.

[2] Mackay, D., and Fraser, A. 2000. "Bioaccumulation of Persistent Organic Chemicals: Mechanisms and Models." Environmental Pollution 110 (3): 375-91.

[3] Connolly, J. P., and Pedersen, C. J. 1988. "A Thermodynamic-based Evaluation of Organic Chemical Accumulation in Aquatic Organisms." Environmental Science \& Technology 22 (1): 99-103.

[4] Rand, G. M., Wells, P. G., and McCarty, L. S. 1995. "Introduction to Aquatic Toxicology." In Fundamentals of Aquatic Toxicology Effects, Environmental Fate, and Risk Assessment. Taylor and Francis Publishers, North Palm Beach, Florida, USA, 3-67.

[5] Gray, J. S. 2002. "Biomagnification in Marine Systems: The Perspective of an Ecologist." Marine Pollution Bulletin 45 (1): 46-52.

[6] Gobas, F. A. 2000. "Bioconcentration and Biomagnification in the Aquatic Environment." In Handbook of Property Estimation Methods for Chemicals, Environmental and Health Sciences, edited by Boethling, R.S., and Mackay, D. Lewis, Boca Raton, 189-231.

[7] Spacie, A., McCarty, L. S., and Rand, G. M. 1995. "Bioaccumulation and Bioavailability in Multiphase Systems." In Fundamentals of Aquatic Toxicology (2nd Edition), edited by Rand G. M. Washington, DC: Taylor and Francis, 493-521.

[8] Barber, M. C., Suarez, L. A., and Lassiter, R. R. 1991. "Modelling Bioaccumulation of Organic Pollutants in Fish with an Application to PCBs in Lake Ontario Salmonids." Canadian Journal of Fisheries \& Aquatic Sciences 48 (2): 318-37.

[9] Wang, W. X. 2002. "Interactions of Trace Metals and
Different Marine Food Chains" Marine Ecology Progress Series 243: 295-309.

[10] Rounick, J. S., Winterbourn, M. J., and Lyon, G. L. 1982. "Differential Utilization of Allochthonous and Autochthonous Inputs by Aquatic Invertebrates in Some New Zealand Streams: A Stable Carbon Isotope Study." Oikos: 191-8.

[11] Hamilton, S. K., Lewis, W. M., and Sippel, S. J. 1992. "Energy Sources for Aquatic Animals in the Orinoco River Floodplain: Evidence from Stable Isotopes." Oecologia 89 (3): 324-30.

[12] Atwell, L., Hobson, K. A., and Welch, H. E. 1998. "Biomagnification and Bioaccumulation of Mercury in an Arctic Marine Food Web: Insights from Stable Nitrogen Isotope Analysis." Canadian Journal of Fisheries \& Aquatic Sciences 55 (5): 1114-21.

[13] Thompson, D. R., Furness, R. W., and Monteiro, L. R. 1998. "Seabirds as Biomonitors of Mercury Inputs to Epipelagic and Mesopelagic Marine Food Chains." Science of the Total Environment 213 (1): 299-305.

[14] Power, M., Klein, G. M., Guiguer, K., and Kwan, M. 2002. "Mercury Accumulation in the Fish Community of a Sub-Arctic Lake in Relation to Trophic Position and Carbon Sources." Journal of Applied Ecology 39 (5): 819-30.

[15] Campbell, L. M., Norstrom, R. J., Hobson, K. A., Muir, D. C., Backus, S., and Fisk, A. T. 2005. "Mercury and Other Trace Elements in a Pelagic Arctic Marine Food Web (Northwater Polynya, Baffin Bay)." Science of the Total Environment 351: 247-63.

[16] Luoma, S. N., and Rainbow, P. S. 2008. Metal Contamination in Aquatic Environments: Science and Lateral Management. Cambridge University Press.

[17] Machiwa, J. F. 2000. "Heavy Metals and Organic Pollutants in Sediments of Dar es Salaam Harbour Prior to Dredging in 1999." Tanzania Journal of Science 26 (1): 29-46.

[18] Kotze, P., Du Preez, H. H., and Van Vuren, J. H. J. 1999. "Bioaccumulation of Copper and Zinc in Oreochromis Mossambicus and Clarias Gariepinus, from the Olifants River, Mpumalanga, South Africa." Water South Africa-Pretoria 25: 99-110.

[19] Ikemoto, T., Tu, N. P. C., Okuda, N., Iwata, A., Omori, K., Tanabe, S., et al. 2008. "Biomagnification of Trace Elements in the Aquatic Food Web in the Mekong Delta, South Vietnam Using Stable Carbon and Nitrogen Isotope Analysis." Archives of Environmental Contamination \& Toxicology 54 (3): 504-15.

[20] Revenga, J. E., Campbell, L. M., Arribere, M. A., and Guevara, S. R. 2012. "Arsenic, Cobalt and Chromium Food Web Biodilution in a Patagonia Mountain Lake." Ecotoxicology \& Environmental Safety 81: 1-10. 
[21] France, R., and Steedman, R. 1996. "Energy Provenance for Juvenile Lake Trout in Small Canadian Shield Lakes as Shown by Stable Isotopes." Transactions of the American Fisheries Society 125 (4): 512-8.

[22] Newell, R. I. E., Marshall, N., Sasekumar, A., and Chong, V. C. 1995. "Relative Importance of Benthic Microalgae, Phytoplankton, and Mangroves as Sources of Nutrition for Penaeid Prawns and Other Coastal Invertebrates from Malaysia." Marine Biology 123 (3): 595-606.

[23] Bouillon, S., Koedam, N., Raman, A., and Dehairs, F. 2002. "Primary Producers Sustaining Macro-invertebrate Communities in Intertidal Mangrove Forests." Oecologia 130 (3): 441-8.

[24] Grebmeier, J. M., McRoy, C. P., and Feder, H. M. 1988. "Pelagic-benthic Coupling on the Shelf of the Northern Bering and Chukchi Seas. I. Food Supply Source and Benthic Biomass." Marine Ecology Progress Series 48 (1): 57-67.

[25] Achituv, Y., Brickner, I., and Erez, J. 1997. "Stable Carbon Isotope Ratios in Red Sea Barnacles (Cirripedia) as an Indicator of Their Food Source." Marine Biology 130 (2): 243-7.

[26] Ponsard, S., and Arditi, R. 2000. "What Can Stable Isotopes $\left(\delta^{15} \mathrm{~N}\right.$ and $\left.\delta^{13} \mathrm{C}\right)$ Tell about the Food Web of Soil Macro-invertebrates?" Ecology 81 (3): 852-64.

[27] Xu, J., Xie, P., Zhang, M., and Yang, H. 2005. "Variation in Stable Isotope Signatures of Seston and a Zooplanktivorous Fish in a Eutrophic Chinese Lake." Hydrobiologia 541 (1): 215-20.

[28] Sheaves, M., and Molony, B. 2000. "Short-circuit in the Mangrove Food Chain.” Marine Ecology Progress Series 199: 97-109.

[29] Alfaro, A. C., Thomas, F., Sergent, L., and Duxbury, M. 2006. "Identification of Trophic Interactions within an Estuarine Food Web (Northern New Zealand) Using Fatty Acid Biomarkers and Stable Isotopes." Estuarine, Coastal and Shelf Science 70 (1): 271-86.

[30] Cabana, G., and Rasmussen, J. B. 1994. "Modelling Food Chain Structure and Contaminant Bioaccumulation Using Stable Nitrogen Isotopes." Nature 372 (6503): 255-7.

[31] Bowles, K. C., Apte, S. C., Maher, W. A., Kawei, M., and Smith, R. 2001. "Bioaccumulation and Biomagnification of Mercury in Lake Murray, Papua New Guinea." Can. J. Fish. Aquat. Sci. 58 (5): 888-97.

[32] Mason, R. P., Laporte, J. M., and Andres, S. 2000. "Factors Controlling the Bioaccumulation of Mercury, Methylmercury, Arsenic, Selenium, and Cadmium by Freshwater Invertebrates and Fish." Archives of Environmental Contamination \& Toxicology 38 (3): 283-97.

[33] Richmond, M. D. 1997. A Guide to the Seashores of Eastern Africa and the Western Indian Ocean Islands.
SIDA (Swedish International Development Cooperation Agency).

[34] Bianchi, G. 1985. FAO Species Identification Sheets for Fishery Purposes. Field Guide to the Commercial Marine and Brackish-water Species of Tanzania. Pakistan: Fisheries and Aquaculture Department.

[35] Newman, M. C., and Zhao, Y. 2005. "Measuring Metals and Metalloids in Water, Sediment and Biological Tissues." In Techniques in Aquatic Toxicology (2nd Edition), edited by Ostrander G. K. Boca Raton, FL: Lewis Publishers/CRC Press, 591-615.

[36] Nauen, C. E. 1983. "Compilation of Legal Limits for Hazardous Substances in Fish and Fisheries Product." FAO, 102.

[37] Cabana, G., and Rasmussen, J. B. 1996. "Comparison of Aquatic Food Chains Using Nitrogen Isotopes." Proceedings of the National Academy of Science 93 (20): 10844-7.

[38] Lopez-Fernandez, H., and Winemiller, K. O. 2005. "Status of Dionda Diaboli and Report of Established Populations of Exotic Fish Species in Lower San Felipe Creek, Val Verde County, Texas." The Southwestern Naturalist 50 (2): 246-51.

[39] Vander-Zanden, M. J., Cabana, G., and Rasmussen, J. B. 1997. "Comparing Trophic Position of Freshwater Fish Calculated Using Stable Nitrogen Isotope Ratios $\left(\delta^{15} \mathrm{~N}\right)$ and Literature Dietary Data." Canadian Journal of Fisheries \& Aquatic Sciences 54 (5): 1142-58.

[40] Merritt, R. W., and Cummins, K. W., eds. 1996. An Introduction to the Aquatic Insects of North America. Kendall Hunt.

[41] Jennings, S., Pinnegar, J. K., Polunin, N. V., and Warr, K. J. 2002. "Linking Size-based and Trophic Analyses of Benthic Community Structure." Marine Ecology Progress Series 226: 77-85.

[42] Vander-Zanden, M. J., and Rasmussen, J. B. 2001. "Variation in $\delta^{15} \mathrm{~N}$ and $\delta^{13} \mathrm{C}$ Trophic Fractionation: Implications for Aquatic Food Web Studies." Limnology \& Oceanography 46 (8): 2061-6.

[43] Thomson, D., Maher, W., and Foster, S. 2007. "Arsenic and Selected Elements in Inter-tidal and Estuarine Marine Algae, South-east Coast, NSW, Australia." Applied Organometallic Chemistry 21 (6): 396-411.

[44] Rahman, M. A., Hasegawa, H., and Lim, R. P. 2012. "Bioaccumulation, Biotransformation and Trophic Transfer of Arsenic in the Aquatic Food Chain." Environmental Research 116: 118-35.

[45] Barwick, M., and Maher, W. 2003. "Biotransference and Biomagnification of Selenium Copper, Cadmium, Zinc, Arsenic and Lead in a Temperate Seagrass Ecosystem from Lake Macquarie Estuary, NSW, Australia." Marine Environmental Research 56 (4): 471-502. 
[46] Hardersen, S., and Wratten, S. D. 1998. "The Effects of Carbaryl Exposure of the Penultimate Larval Instars of Xathocnemis Zealandica on Emergence and Fluctuating Asymmetry." Ecotoxicology 7 (5): 297-304.

[47] Fernandes, T. F., Christofi, N., and Stone, V. 2007. "The Environmental Implications of Nanomaterials." In Nanotoxicology: Characterization, Dosing and Health Effects, edited by Monteiro-Riviere, N., and Tran, C. L. CRC Press, Boca Raton, FL, USA, 405-20.

[48] Woolson, E. A. 1975. "Bioaccumulation of Arsenicals." In Arsenical Pesticides, edited by Woolson, E. A. Washington, D.C.: American Chemical Society, ACS Symposium.

[49] Wagemann, R., Snow. N. B., Rosenberg, D. M., and Lutz. A. 1978. "Arsenic in Sediments, Water and Aquatic Biota from Lakes in the Vicinity of Yellowknife, Northwest Territories, Canada." Archives of Environmental Contamination \& Toxicology 7 (1): 169-91.

[50] Chen, C. Y., and Folt, C. L. 2000. "Bioaccumulation and Diminution of Arsenic and Lead in a Freshwater Food Web." Environmental Science \& Technology 34 (18): 3878-84.

[51] Karez, C. S., Magalhaes, V. F., Pfeiffer, W. C., and Amado Filho, G. M. 1994. "Trace Metal Accumulation by Algae in Sepetiba Bay, Brazil." Environmental Pollution 83 (3): 351-6.

[52] Lee, B. G., Griscom, S. B., Lee, J. S., Choi, H. J., Koh, C. H., Luoma, S. N., et al. 2000. "Influences of Dietary Uptake and Reactive Sulfides on Metal Bioavailability from Aquatic Sediments." Science 287 (5451): 282-4.

[53] Romeo, M., Siau. Y., Sidoumou, Z., and Gnassia-Barelli, M. 1999. "Heavy Metal Distribution in Different Fish Species from the Mauritania Coast." Science of the Total Environment 232 (3): 169-75.

[54] Kidd, K. A., Schindler, D. W., Hesslein, R. H., and Muir, D. C. G. 1995. "Correlation between Stable Nitrogen
Isotope Ratios and Concentrations of Organochlorines in Biota from a Freshwater Food Web." Science of the Total Environment 160: 381-90.

[55] Al-Reasi, H. A., Ababneh, F. A., and Lean, D. R. 2007. "Evaluating Mercury Biomagnification in Fish from a Tropical Marine Environment Using Stable Isotopes $\left(\delta^{13} \mathrm{C}\right.$ and $\left.\delta^{15} \mathrm{~N}\right)$. " Environmental Toxicology \& Chemistry 26 (8): 1572-81.

[56] Luoma, S. N. 1989. "Can We Determine the Biological Availability of Sediment-bound Trace Elements?" Hydrobiologia 176 (1): 379-96.

[57] Mamboya, F. A. 2007. "Heavy Metal Contamination and Toxicity: Studies of Macroalgae from the Tanzania Coast." Doctoral dissertation, Botaniska institutionen.

[58] Elmaci, A., Teksoy, A., Topac, F. O., and Özengin, N. 2007. "Assessment of Heavy Metals in Lake Uluabat, Turkey." African Journal of Biotechnology 6 (19): 2236-44.

[59] Eisler, R. 1981. Trace Metal Concentrations in Marine Organisms. New York: Pergamon Press.

[60] Rainbow, P. S. 1993. "The Significance of Trace Metal Concentrations in Marine Invertebrates." In Ecotoxicology of Metals in Invertebrates, edited by Dallinger, R., and Rainbow, P. S. Chelsea, USA: Lewis Publishers, 3-23.

[61] Romeo, M., Siau, Y., Sidoumou, Z., and Gnassia-Barelli, M. 1999. "Heavy Metal Distribution in Different Fish Species from the Mauritania Coast." Science of the Total Environment 232 (3): 169-75.

[62] Canli, M., and Atli, G. 2003. "The Relationships between Heavy Metal (Cd, Cr, Cu, Fe, Pb, Zn) Levels and the Size of Six Mediterranean Fish Species." Environmental Pollution 121 (1): 129-36.

[63] Friberg, L., Norberg, G. F., and Vouk, V. B. 1979. Handbook of Metal Toxicology. Amsterdam: Elsevier/North Holland Biomedical Press. 